\title{
Cationic, Neutral, and Anionic Hydrides of Iridium with PSiP Pincers
}

\author{
Elizabeth Suárez, ${ }^{\dagger}$ Pablo Plou, ${ }^{\dagger}$ Dmitry G. Gusev, ${ }^{\ddagger}$ Marta Martín, ${ }^{*}{ }^{\dagger}$ and Eduardo Sola*, ${ }^{\dagger}$ \\ †Instituto de Síntesis Química y Catálisis Homogénea (ISQCH), CSIC-Universidad de Zaragoza, E50009, Spain \\ ${ }^{\ddagger}$ Department of Chemistry, Wilfrid Laurier University, Waterloo, Ontario N2L 3C5, Canada \\ Supporting Information Placeholder
}

\begin{abstract}
This work describes synthetic routes from the known precursor $\left[\mathrm{IrClH}\left\{\kappa P, P, \mathrm{Si}-\mathrm{Si}(\mathrm{Me})\left(\mathrm{C}_{6} \mathrm{H}_{4}-2-\mathrm{PiPr}_{2}\right)_{2}\right\}\right]$ (1) to new hydride and polyhydride derivatives. Substituting the chloride ligand with triflate leads to the five-coordinate complex $\left[\mathrm{IrH}\left\{\kappa \mathrm{O}-\mathrm{O}_{3} \mathrm{~S}\left(\mathrm{CF}_{3}\right)\right\}\left\{\kappa P, P, \mathrm{Si}-\mathrm{Si}(\mathrm{Me})\left(\mathrm{C}_{6} \mathrm{H}_{4}-2-\mathrm{PiPr}_{2}\right)_{2}\right\}\right]$ (2), which can undergo reversible coordination of water or $\mathrm{H}_{2}$ to generate, respectively, the cationic derivative $\left[\operatorname{IrH}\left\{\kappa P, P, S i-\mathrm{Si}(\mathrm{Me})\left(\mathrm{C}_{6} \mathrm{H}_{4}-2-\right.\right.\right.$ $\left.\left.\left.\mathrm{PiPr}_{2}\right)_{2}\right\}\left(\mathrm{OH}_{2}\right)_{2}\right]\left(\mathrm{CF}_{3} \mathrm{SO}_{3}\right)$ (3) or the neutral trans-hydridedihydrogen $\quad\left[\mathrm{IrH}\left\{\kappa \mathrm{O}-\mathrm{O}_{3} \mathrm{~S}\left(\mathrm{CF}_{3}\right)\right\}\left\{\kappa P, P, \mathrm{Si}-\mathrm{Si}(\mathrm{Me})\left(\mathrm{C}_{6} \mathrm{H}_{4}-2-\right.\right.\right.$ $\left.\left.\left.\mathrm{PiPr}_{2}\right)_{2}\right\}\left(\eta^{2}-\mathrm{H}_{2}\right)\right](6)$ in equilibrium. The use of acetonitrile or $\mathrm{CO}$ excess instead of water produces stable analogues of $\mathbf{3}$ (complexes 4 or 5 , respectively). Reaction between 1 and $\mathrm{NaBH}_{4}$ affords the tetrahydroborate derivative $\quad\left[\mathrm{IrH}\left\{\kappa^{2} \mathrm{H}-\mathrm{H}_{2} \mathrm{BH}_{2}\right\}\{\kappa P, P, \mathrm{Si}\right.$ $\left.\left.\mathrm{Si}(\mathrm{Me})\left(\mathrm{C}_{6} \mathrm{H}_{4}-2-\mathrm{PiPr}_{2}\right)_{2}\right\}\right]$ (7), which can be protonated with triflic acid to form 2, or with $\mathrm{HBF}_{4}$ to give the dinuclear cationic derivative $\quad\left[\left(\mu: \kappa^{2} H, \kappa^{2} H-B_{4}\right)\left[\operatorname{IrH}\left\{\kappa P, P, S i-S i(M e)\left(\mathrm{C}_{6} \mathrm{H}_{4}-2-\right.\right.\right.\right.$ $\left.\left.\left.\left.\mathrm{PiPr}_{2}\right)_{2}\right\}\right]_{2}\right]\left(\mathrm{BF}_{4}\right)(\mathbf{8})$. The reactions of 7 with alcohols afford either the dihydride-carbonyl $\quad\left[\mathrm{IrH}_{2}\left\{\kappa P, P, S i-\mathrm{Si}(\mathrm{Me})\left(\mathrm{C}_{6} \mathrm{H}_{4}-2-\right.\right.\right.$ $\left.\left.\left.\mathrm{PiPr}_{2}\right)_{2}\right\}(\mathrm{CO})\right]$ (9) or the known tetrahydride $\left[\mathrm{IrH}_{4}\{\kappa P, P, S i-\right.$ $\left.\left.\mathrm{Si}(\mathrm{Me})\left(\mathrm{C}_{6} \mathrm{H}_{4}-2-\mathrm{PiPr}_{2}\right)_{2}\right\}\right]$ (10), depending on the ease of alcohol decarbonylation. NMR observations and DFT calculations on the fluxional behavior of $\mathbf{1 0}$ indicate that the spatial contour of the mer PSiP framework conditions hydride ligand exchanges. Complex 10 reacts with $\mathrm{NaH}$ in THF to form the anionic trihydride $\left[\mathrm{IrH}_{3}\left\{\kappa P, P, \mathrm{Si}-\mathrm{Si}(\mathrm{Me})\left(\mathrm{C}_{6} \mathrm{H}_{4}-2-\mathrm{PiPr}_{2}\right)_{2}\right\}\right] \mathrm{Na}(\mathbf{1 1})$, which exists as a mixture of fac and mer isomers in equilibrium.
\end{abstract}

\section{INTRODUCTION}

Transition metal hydride complexes are almost ubiquitous in organometallic catalysis and energy conversion and storage paradigms. ${ }^{1}$ In particular, those of iridium promote or mediate catalytic transformations of actual or potential industrial importance, 2,3 such as hydrogenations ${ }^{4,5}$ and $\mathrm{C}-\mathrm{H}$ bond functionalizations. ${ }^{6-9}$ Behind this singular reactivity are factors such as the exceptional mobility of metal-bonded $\mathrm{H}$ atoms, ${ }^{10}$ which enables different facile inner- and outer-sphere migrations, ${ }^{11,12}$ and their strong $\sigma$ donor character and trans influence as ligands, ${ }^{13}$ which often also determine the structures. The latter, however, become less decisive when other strong $\sigma$-donor ligands are present, as observed for example in hydride complexes with silyl- (PSiP) ${ }^{14}$ or boryldonor (PBP) pincers. ${ }^{15}$ These ligands have emerged capable of promoting hydride complexes with distinctive structures, likely to be more reactive than conventional ones. ${ }^{16}$ Also, these strong $\sigma$ donor pincers have been observed to expedite migratory insertions into $\mathrm{M}-\mathrm{H}$ bonds, thus being particularly suitable for challenging catalytic transformations such as those involving carbon diox- ide. ${ }^{17}$ Aimed at extending this chemistry to compound types that can fulfill the requirements of different catalytic transformations, we describe here the preparations and structures of a variety of iridium PSiP hydrides, including dihydrogen and anionic derivatives, still unknown in the chemistry of these pincers. ${ }^{18}$ The work starts from the five-coordinate precursor $[\operatorname{IrClH}\{\kappa P, P, S i$ $\left.\left.\mathrm{Si}(\mathrm{Me})\left(\mathrm{C}_{6} \mathrm{H}_{4}-2-\mathrm{PiPr}_{2}\right)_{2}\right\}\right]$ (1), previously reported by Shimada et al. ${ }^{19}$ and, besides the new complexes, also describes in detail the dynamic behavior in solution of the known tetrahydride $\left[\mathrm{IrH}_{4}\left\{\kappa P, P, \mathrm{Si}-\mathrm{Si}(\mathrm{Me})\left(\mathrm{C}_{6} \mathrm{H}_{4}-2-\mathrm{PiPr}_{2}\right)_{2}\right\}\right](\mathbf{1 0})$.

\section{RESULTS AND DISCUSSION}

Just as its analogues with $t \mathrm{Bu}^{20}$ and $\mathrm{Cy}^{21}$ substituents at the phosphorus, and other complexes with related PSiP ligands, ${ }^{16}$ the unsaturated complex $\mathbf{1}$ displays a solid state structure in which the empty coordination site lies trans to the silicon atom, with $\mathrm{Cl}-\mathrm{Ir}-\mathrm{H}$ and $\mathrm{P}-\mathrm{Ir}-\mathrm{P}$ angles of 159.8(12) and 163.37(3) ${ }^{\circ}$, respectively (see Supporting Information). The range of possible reactions enabled by this coordination vacancy can be extended by replacing the chloride ligand with the more labile triflate: a transformation cleanly completed by one equivalent of methyl triflate in dichloromethane (Scheme 1).

\section{Scheme 1}

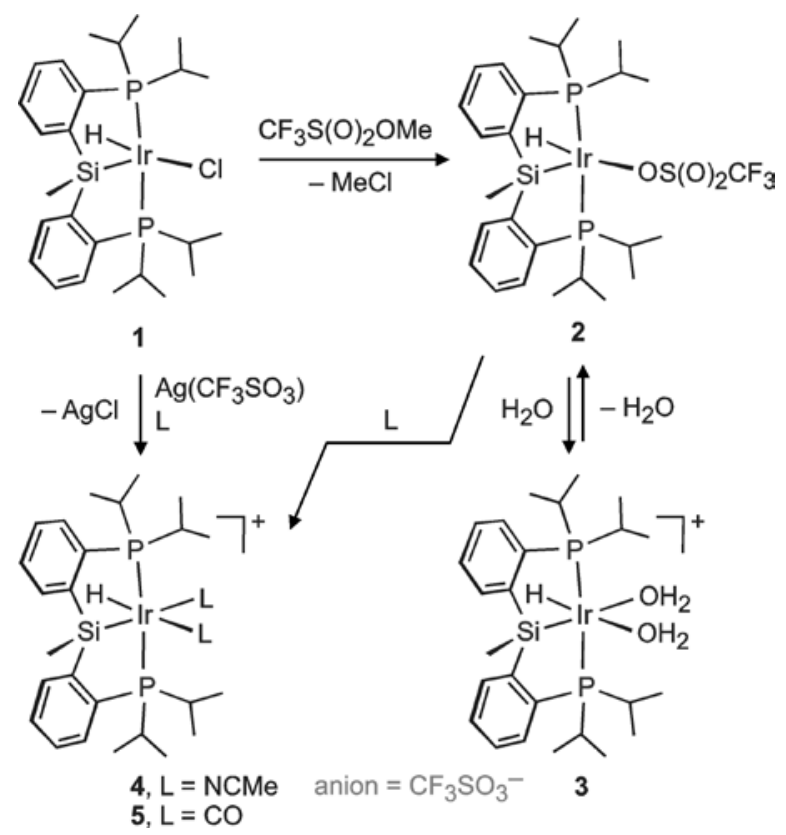

The resulting complex, $\left[\mathrm{IrH}\left\{\kappa \mathrm{O}-\mathrm{O}_{3} \mathrm{~S}\left(\mathrm{CF}_{3}\right)\right\}\{\kappa P, P, \mathrm{Si}-\right.$ $\left.\left.\mathrm{Si}(\mathrm{Me})\left(\mathrm{C}_{6} \mathrm{H}_{4}-2-\mathrm{PiPr}_{2}\right)_{2}\right\}\right]$ (2), was found to be relatively stable and easy to handle, in contrast to the affinity for traces of adventitious water of its analogue with an aliphatic backbone at the PSiP lig- 
and. $^{22}$ This analogue was reported to readily form a $\kappa O, P, P$ $\mathrm{P}(\mathrm{SiOH}) \mathrm{P}$ dihydride complex after cleaving a water molecule and inserting the $\mathrm{OH}$ fragment into the $\mathrm{Si}-\mathrm{Ir}$ bond. Instead of such an irreversible transformation, the treatment of $\mathbf{2}$ with water in a NMR tube in $\mathrm{CD}_{2} \mathrm{Cl}_{2}$ was observed to provoke just small shifts in most of the NMR signals, including the diagnostic singlets in the ${ }^{31} \mathrm{P}\left\{{ }^{1} \mathrm{H}\right\}$ and ${ }^{19} \mathrm{~F}$ spectra, at $\delta 69.60$ and -77.49 respectively, and the triplet corresponding to the hydride ligand in the ${ }^{1} \mathrm{H}$ high-field region, at $\delta-29.52\left(J_{\mathrm{HP}}=14.9 \mathrm{~Hz}\right)$. Decreasing the temperature provoked decoalescence of each of these shifted signals into two, whose relative intensity depended on the amount of added water. One set of signals match those of complex $\mathbf{2}$ while the other indicates formation of a new monohydride species, 3 . The most characteristic ${ }^{1} \mathrm{H}$ NMR signals of this new complex at $173 \mathrm{~K}$ are a broad triplet at $\delta-28.86\left(J_{\mathrm{HP}} \approx 16 \mathrm{~Hz}\right.$ ) and two equal broad resonances at $\delta 4.30$ and 4.89 , whose integrals suggest that correspond to two non-equivalent water ligands. Consistently, the ${ }^{19} \mathrm{~F} \mathrm{NMR}$ signal of the new species appears close to $\delta-79$, as expected for a free triflate anion in this solvent (see below). ${ }^{22}$

The proposed structures of $\mathbf{2}$ and its cationic water adduct $\left[\mathrm{IrH}\left\{\kappa P, P, \mathrm{Si}\right.\right.$-Si(Me) $\left.\left.\left(\mathrm{C}_{6} \mathrm{H}_{4}-2-\mathrm{PiPr}_{2}\right)_{2}\right\}\left(\mathrm{OH}_{2}\right)_{2}\right]\left(\mathrm{CF}_{3} \mathrm{SO}_{3}\right)$ (3) were corroborated by $\mathrm{X}$-ray diffraction in crystals obtained from hexane solutions of $\mathbf{2}$ treated with small amounts (microliters) of water, and stored at $253 \mathrm{~K}$. Remarkably, such a treatment led to the formation of co-crystals in which $\mathbf{2}$ and $\mathbf{3}$ share the crystal unit cell, hold together through hydrogen bonding (Figure 1).

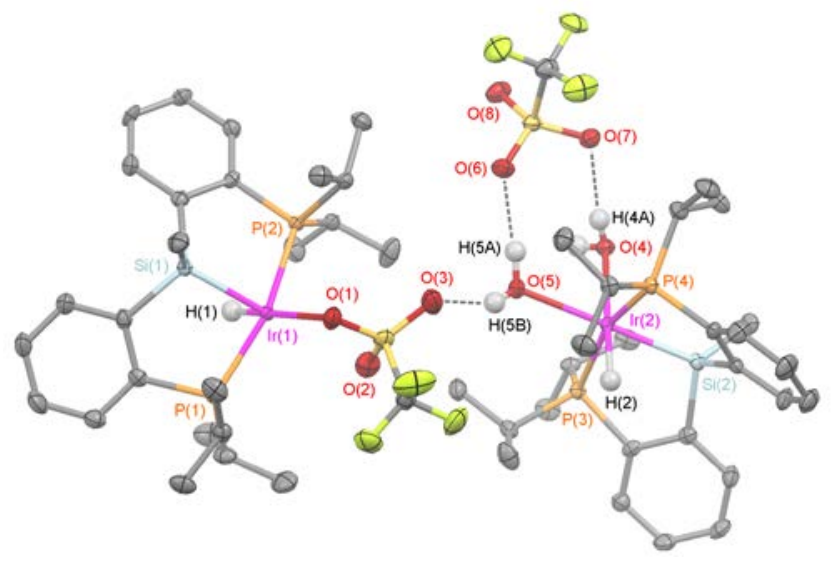

Figure 1. Structures of the neutral triflate complex $2(\operatorname{Ir}(1)$ in the left of the image) and its cationic water adduct $3(\operatorname{Ir}(2))$ as determined in co-crystals obtained from $\mathbf{2}$ in "wet" hexane. Ellipsoids for the anisotropic displacement parameters at the 50\% level. Hydrogen atoms except hydrides and those involved in hydrogen bonds (dotted lines) have been omitted for the sake of clarity. For bond distances and angles, see Supporting Information.

The structure of $\mathbf{2}$ found in the co-crystal is consistent with the NMR data collected for the pure compound, which indicate a mer coordination of the PSiP ligand ${ }^{23}$ and an anti orientation of the hydride relative to the methyl at silicon. As a result of the monodentate coordination of the triflate, the complex remains fivecoordinate: a feature difficult to ascertain in solution on the basis of NMR data. ${ }^{22}$ On the other hand, the cation of $\mathbf{3}$ is sixcoordinate and features two weakly bonded water molecules, as inferred from the $\operatorname{Ir}(2)-\mathrm{O}$ bond distances: $2.249(3) \AA$ trans to hydride and 2.318(3) $\AA$ trans to silicon. The four hydrogens of these water molecules, which were refined freely, are involved in hydrogen bonding with triflate oxygens, with $\mathrm{H} \cdots \mathrm{O}$ distances in the range $1.96-2.19 \AA$. The cation also retains the mer coordination mode of the pincer as well as the anti orientation of the hydride.
The reversible reaction between $\mathbf{2}$ and water leading to $\mathbf{3}$ confirms the higher robustness of the actual (PSiP)Ir skeleton compared to the aliphatic one, and suggests that triflate displacement from 2 by conventional ligands (L) can easily lead to a variety of cationic compounds of general formula $[\operatorname{IrH}\{\kappa P, P, S i$ $\left.\left.\mathrm{Si}(\mathrm{Me})\left(\mathrm{C}_{6} \mathrm{H}_{4}-2-\mathrm{PiPr}_{2}\right)_{2}\right\}(\mathrm{L})_{2}\right]\left(\mathrm{CF}_{3} \mathrm{SO}_{3}\right)$. These are exemplified for $\mathrm{L}=\mathrm{NCMe}(4)$ and CO (5) in Scheme 1, which also illustrates an alternative preparation of these compounds from $\mathbf{1}$, silver triflate and ligand excess. Complexes $\mathbf{4}$ and $\mathbf{5}$ were isolated as analytically pure solids and characterized by NMR as structurally analogous to 3 .

Complex 2 was also found capable of coordinating very weak ligands such as dihydrogen, although the product (6 in Scheme 2) proved too labile to be isolated as a solid.

\section{Scheme 2}

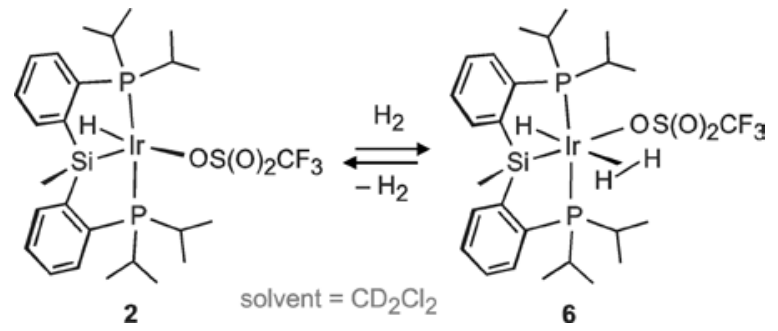

As observed for water, dissolving $\mathrm{H}_{2}$ in $\mathrm{CD}_{2} \mathrm{Cl}_{2}$ solutions of 2 at room temperature provoked shifts and broadenings of the NMR signals that reveal the reversible formation of new complexes in equilibrium with 2 . Decoalescence of the broad resonances occurred below $260 \mathrm{~K}$, rendering observable the hydride ${ }^{1} \mathrm{H}$ NMR signals shown in Figure 2, which correspond to the major species at low temperature. The broad signal at $\delta-1.65$ integrates twice as much as the triplet at $\delta-12.26\left(J_{\mathrm{HP}}=13.4 \mathrm{~Hz}\right)$, and displays a minimum $T_{1}$ relaxation time of $7 \mathrm{~ms}$, characteristic of a dihydrogen ligand. ${ }^{24}$ Within the range of temperature in which these ${ }^{1} \mathrm{H}$ NMR signals are observable, the nOesy experiments do not evidence either their spatial proximity or chemical exchange between them, thus suggesting a trans relative position of the hydride and dihydrogen ligands in the coordination sphere of the complex.

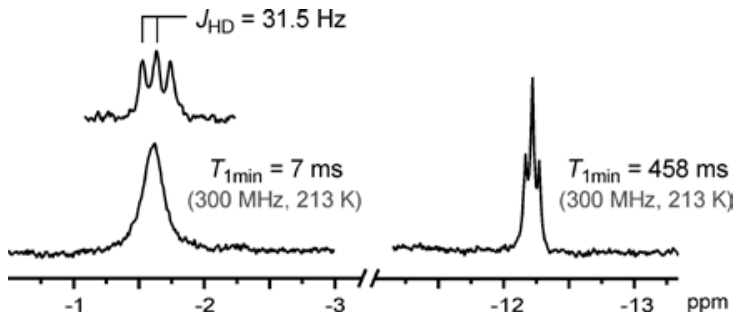

Figure 2. ${ }^{1} \mathrm{H}$ NMR hydride signals of complex 6 in $\mathrm{CD}_{2} \mathrm{Cl}_{2}$ at 233 $\mathrm{K}$. The inset corresponds to the remaining signal observed after treatment of $\mathbf{2}$ with $\mathrm{D}_{2}$ at this temperature.

The low temperature NMR spectra also confirm triflate coordination to $\mathbf{6}$. Figure 3 compares the evolution with temperature of ${ }^{19} \mathrm{~F}$ spectra recorded for a sample of $\mathbf{2}$ with or without dissolved $\mathrm{H}_{2}$; in the presence of added water to reveal the chemical shift of the free triflate anion released after formation of adduct 3 . Clearly, the major product formed under $\mathrm{H}_{2}$ shows a ${ }^{19} \mathrm{~F}$ chemical shift consistent with a coordinated triflate. Nevertheless, these and other spectra recorded for this equilibrium also suggest that the coordination behavior of $\mathrm{H}_{2}$ does not limit to the formation of complex 6. In fact, the ${ }^{19} \mathrm{~F}$ spectrum under $\mathrm{H}_{2}$ at $193 \mathrm{~K}$ illustrates that the signal of $\mathbf{6}$ still broadens and shifts at low temperature while the amount of free triflate increases, suggesting that triflate 
could eventually be released from 6 due to further $\mathrm{H}_{2}$ coordination. Also, the coordination of $\mathrm{H}_{2}$ in the position cis to hydride, expected to be kinetically favored in view of the structure of $\mathbf{2}$, is suggested by the fast deuteration of this ligand under $\mathrm{D}_{2},{ }^{25}$ unlikely to happen in the observable trans complex 6. Even though the $\mathrm{H} / \mathrm{D}$ scrambling was found to be rapid (minutes) at low temperature, the ${ }^{1} \mathrm{H}$ NMR spectra recorded at short reaction times allowed the observation of a residual signal for the $\eta^{2}$-(HD) isotopomer of 6 featuring a $J_{\mathrm{HD}}$ coupling constant of $31.5 \pm 2 \mathrm{~Hz}$ (Figure 2). This value leads to a dihydrogen ligand $\mathrm{H}-\mathrm{H}$ distance of $0.91 \pm$ $0.04 \AA{ }^{26}$ fully compatible with the estimations derived from the $T_{1 \text { min }}$ relaxation time. ${ }^{24}$

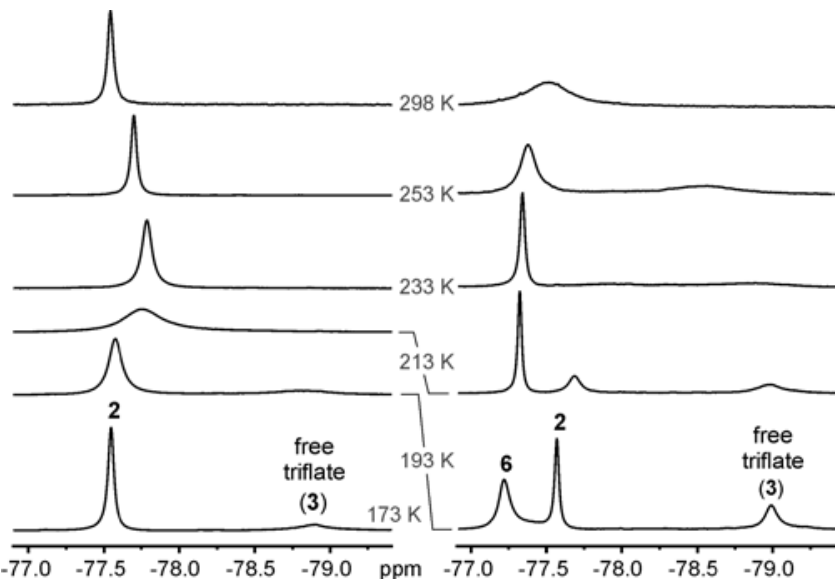

Figure 3. Evolution with temperature of the ${ }^{19} \mathrm{~F}$ NMR spectrum of: (left) a solution of 2 and 0.4 equivalents of water in $\mathrm{CD}_{2} \mathrm{Cl}_{2}$ and (right) the same solution under $\mathrm{H}_{2}$ atmosphere (ca.1 bar).

The chloride ligand of $\mathbf{1}$ can also be removed using sodium borohydride, to form the hydride-tetrahydroborate complex [IrH $\left.\left(\kappa^{2} H-\mathrm{H}_{2} \mathrm{BH}_{2}\right)\left\{\kappa P, P, \mathrm{Si}-\mathrm{Si}(\mathrm{Me})\left(\mathrm{C}_{6} \mathrm{H}_{4}-2-\mathrm{PiPr}_{2}\right)_{2}\right\}\right]$ (7 in Scheme $3)$. Unlike the triflate derivative 2 , complex 7 is six-coordinate as a result of the most common $\kappa^{2} H$ coordination of the tetrahydroborate ligand (Figure 4) ${ }^{27}$ As in the previous complexes, the pincer coordinates in the mer fashion and the terminal hydride occupies the face anti to the methyl at silicon.

\section{Scheme 3}

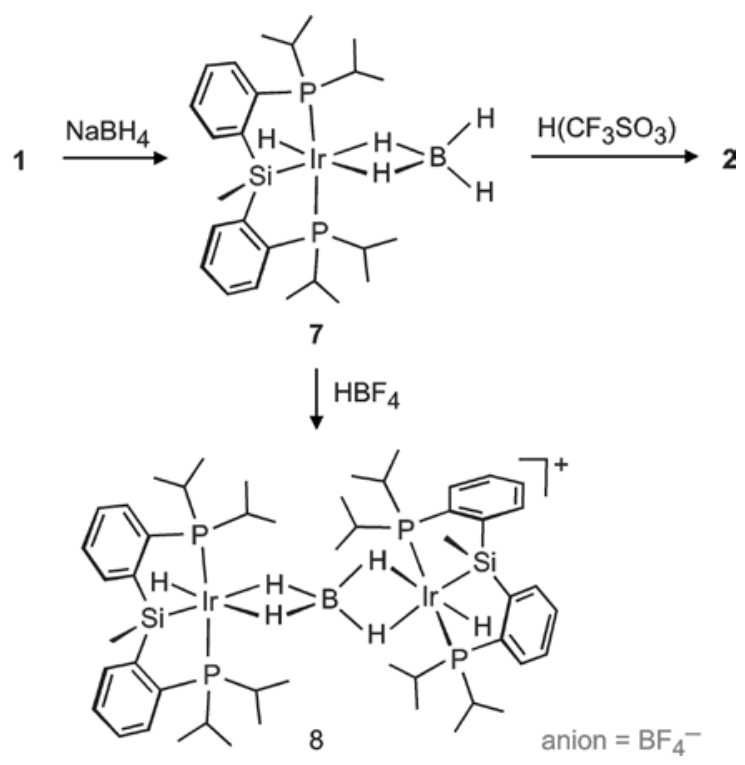

In agreement with the solid state structure, the ${ }^{1} \mathrm{H}$ NMR spectrum of 7 in $\mathrm{C}_{6} \mathrm{D}_{6}$ displays three signals in the hydride region: two broad resonances for the two non-equivalent bridges, at $\delta-3.91$ and -7.11 , and a triplet of doublets for the terminal hydride, at $\delta$ $-17.89\left(J_{\mathrm{HP}}=15.5\right.$ and $J_{\mathrm{HH}}=8.1 \mathrm{~Hz}$, respectively $)$. The latter $J_{\mathrm{HH}}$ constant results from coupling to the bridging hydride in trans, $\mathrm{H}(1 \mathrm{C})$ in the structure of Figure 4, as deduced from selective ${ }^{1} \mathrm{H}$ NMR homodecoupling experiments and the ${ }^{1} \mathrm{H}$ nOesy spectrum (see Supporting Information). This latter spectrum also evidences chemical exchange among the two equivalent terminal $\mathrm{B}-\mathrm{H}$ hydrogens, which share a broad signal at $\delta 7.60$, and the bridging hydride $\mathrm{H}(\mathrm{DD})$. In contrast, neither the other bridging hydride $\mathrm{H}(1 \mathrm{C})$ nor the $\mathrm{Ir}-\mathrm{H}(1)$ terminal one join this or another chemical exchange below $350 \mathrm{~K}$. This exchange scheme is that expected for a facile release of the tetrahydroborate arm trans to silicon.

As shown below, complex 7 constitutes a convenient entry into the chemistry of neutral and anionic polyhydrides. Yet, it can also afford cationic derivatives after treatment with Brønsted acids. In fact, its reaction with excess triflic acid in non-coordinating solvents quantitatively produced 2 . In contrast, using $\mathrm{HBF}_{4}$ as proton source stopped the reaction at an intermediate stage, affording the dinuclear cationic species $\left[\left(\mu: \kappa^{2} H, \kappa^{2} H-B_{4}\right)[\operatorname{IrH}\{\kappa P, P, S i-\right.$ $\left.\left.\left.\mathrm{Si}(\mathrm{Me})\left(\mathrm{C}_{6} \mathrm{H}_{4}-2-\mathrm{PiPr}_{2}\right)_{2}\right\}\right]_{2}\right]\left(\mathrm{BF}_{4}\right) \quad$ (8, Scheme 3). This complex readily precipitated from the reaction media when the protonation was carried out in diethyl ether, and was also observed to be the major product in the homogeneous reaction in dichloromethane, regardless the equivalents of acid employed. Seemingly, in the absence of coordinating anions or solvents, expanding tetrahydroborate coordination mode to bridging is the only remaining option to offset the partial breakdown of this ligand, while protects it from further protonation. Indeed, coordination to an additional cationic fragment is expected to reduce tetrahydroborate nucleophilicity, while the PSiP ligand substituents are likely to provide steric protection, as inferred from the X-ray structure of Figure 4.
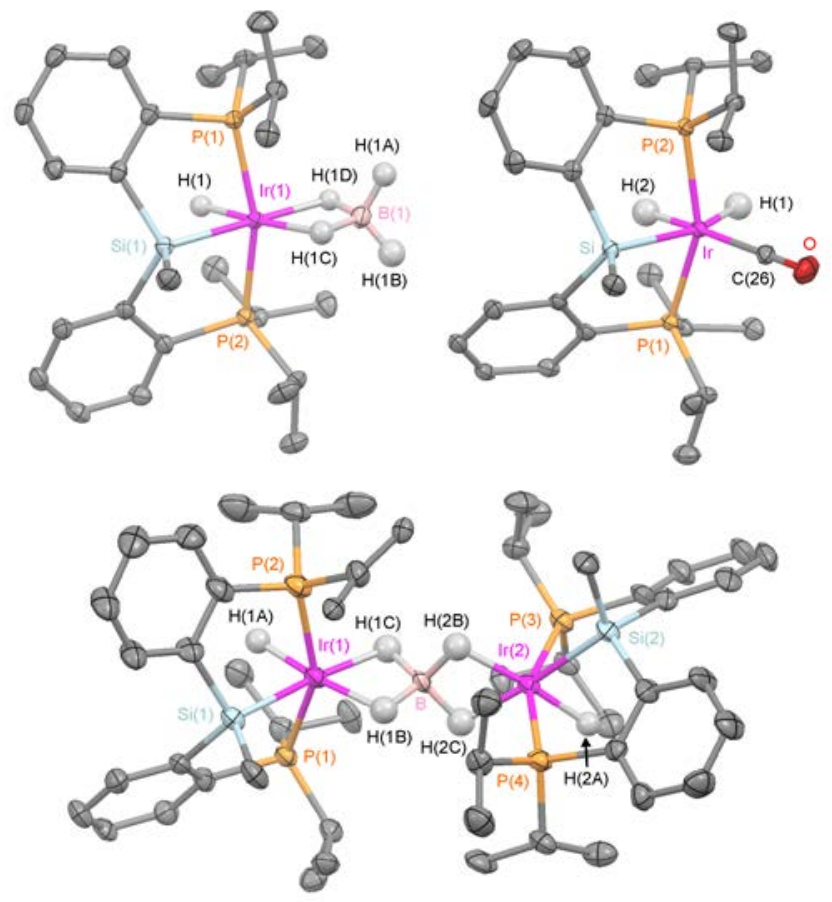

Figure 4. Structures of $\mathbf{7}$ (above left), the cation of $\mathbf{8}$ (below), and $\mathbf{9}$ (above right). Only one of the two independent molecules of $\mathbf{8}$ is represented. Ellipsoids for the anisotropic displacement parameters at the $50 \%$ level. Hydrogen atoms except hydrides have been omitted for the sake of clarity. For bond distances and angles, see Supporting Information. 
In agreement with the $C_{2}$-symmetric structure found in the solid state, the solution ${ }^{31} \mathrm{P}\left\{{ }^{1} \mathrm{H}\right\}$ NMR of 8 shows a single AB pattern with a $J_{\mathrm{PP}}$ coupling constant of $261.9 \mathrm{~Hz}$ : in the range expected for mutually trans phosphorus. In the ${ }^{1} \mathrm{H}$ NMR spectrum, the bridging tetrahydroborate ligand features broad signals at $\delta-3.57$ and -3.28 . The two equivalent terminal hydrides display a ddd signal at $\delta-16.97$, with two similar $J_{\mathrm{HP}}$ coupling constants of about $17.3 \mathrm{~Hz}$ and just one observable $J_{\mathrm{HH}}$ coupling of $4.5 \mathrm{~Hz}$. No chemical exchange among hydrides was detected in this case.

The reactions of 7 with alcohols led to either the dihydridecarbonyl derivative $\left[\mathrm{IrH}_{2}\left\{\kappa P, P, \mathrm{Si}-\mathrm{Si}(\mathrm{Me})\left(\mathrm{C}_{6} \mathrm{H}_{4}-2-\mathrm{PiPr}_{2}\right)_{2}\right\}(\mathrm{CO})\right]$ (9) or the tetrahydride $\left[\operatorname{IrH}_{4}\left\{\kappa P, P, S i-\mathrm{Si}(\mathrm{Me})\left(\mathrm{C}_{6} \mathrm{H}_{4}-2-\mathrm{PiPr}_{2}\right)_{2}\right\}\right]$ (10) (Scheme 4), depending on the ease of alcohol decarbonylation. $^{28}$ Thus, primary alcohols such as methanol or ethanol quantitatively afforded $\mathbf{9}$, whereas $\mathbf{1 0}$ was the main product upon treatment with isopropanol. Complex $\mathbf{1 0}$ was also the product after reaction of $\mathbf{7}$ with water in toluene. A closely related preparation of 10, and the $\mathrm{X}$-ray structure of its analogue with $t \mathrm{Bu}$ instead of $i$ Pr substituents have been previously reported. ${ }^{19}$

\section{Scheme 4}

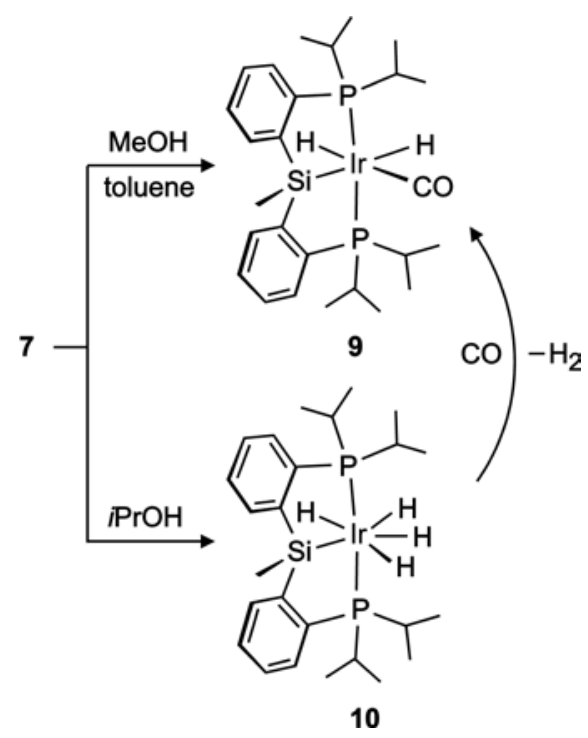

The carbonyl complex 9 was obtained as a single isomer, whose structure is that shown in Scheme 4 and Figure 4. This isomer was also that quantitatively formed after reaction of the tetrahydride 10 with excess $\mathrm{CO}$. This evinces the competence of the mer-PSiP framework to define preferred coordination positions, even for incoming molecules as small as carbon monoxide. A strong $v(C O)$ absorption at $1941 \mathrm{~cm}^{-1}$ in the IR spectrum of 9 confirms the presence of the carbonyl ligand, which also gives rise to a characteristic triplet at $\delta 181.82\left(J_{\mathrm{CP}}=5.7 \mathrm{~Hz}\right)$ in the ${ }^{13} \mathrm{C}\left\{{ }^{1} \mathrm{H}\right\}$ NMR spectrum. Two resonances in the ${ }^{1} \mathrm{H}$ NMR spectrum, at $\delta-13.95$ and -10.97 in $\mathrm{CDCl}_{3}$, showing a mutual coupling constant of $3.4 \mathrm{~Hz}$ and displaying mutual nOe effects, confirm the cis relative position of the two hydride ligands. No chemical exchange among hydrides was detected in this case either.

On the contrary, as previously reported, ${ }^{19}$ the tetrahydride $\mathbf{1 0}$ displays a single high-field resonance in the room temperature ${ }^{1} \mathrm{H}$ NMR spectrum that corresponds to four rapidly exchanging hydride ligands. At low temperature (Figure 5), this average resonance decoalesces into two of relative integral 3:1, which feature a mutual $J_{\mathrm{HH}}$ coupling constant of $6.2 \mathrm{~Hz}$. The minimum $T_{1}$ relaxation time of these hydride resonances is attained below decoalescence $\left(400 \mathrm{MHz}\right.$, THF- $\left.d_{8}\right)$, at about $220 \mathrm{~K}$, and reaches a value around $200 \mathrm{~ms}$ in both signals (see Supporting Information). Although this discards the presence of direct $\mathrm{H}-\mathrm{H}$ bonds and points to a classical tetrahydride structure, the intriguing 3:1 decoalescence pattern may conceivably suggest the involvement of some $\mathrm{Si}-\mathrm{H}$ bonding interaction: a relatively common feature in the chemistry of PSiP pincers. ${ }^{29-32}$ Such a possibility was examined via a series of DFT calculations in THF, that proved to be inconclusive. Whereas PBE0 and wB97X-D optimized geometries of $\mathbf{1 0}$ are adequately described as $\operatorname{Ir}(\mathrm{V})$ tetrahydrides with the closest $\mathrm{Si}-\mathrm{H}$ distances of 2.21 and $2.07 \AA$, respectively, the MN15-L optimized structure possesses a bridging hydride at 1.79 $\AA$ from silicon and $1.67 \AA$ from the metal. Further calculations found two higher-energy minima corresponding to trans- and cis, syn-Ir(III) dihydrides: $\quad\left[\mathrm{IrH}_{2}\left(\eta^{2}-\mathrm{H}_{2}\right)\left\{\kappa P, P, S i-\mathrm{Si}(\mathrm{Me})\left(\mathrm{C}_{6} \mathrm{H}_{4}-2-\right.\right.\right.$ $\left.\left.\mathrm{PiPr}_{2}\right)_{2}\right\}$ ] (Figure 6). The third possible dihydrogen structure, with the $\mathrm{H}_{2}$ ligand anti to the methyl at silicon, could be optimized at the MN15-L level, but was not found at the PBE0 level. The results of our calculations mostly resemble those obtained for the parent pincer tetrahydrides (PCP) $\mathrm{IrH}_{4}$ and (POCOP) $\mathrm{IrH}_{4}$, although obviously, for these higher-symmetry complexes the two cis-dihydride-dihydrogen minima are degenerate. ${ }^{33}$

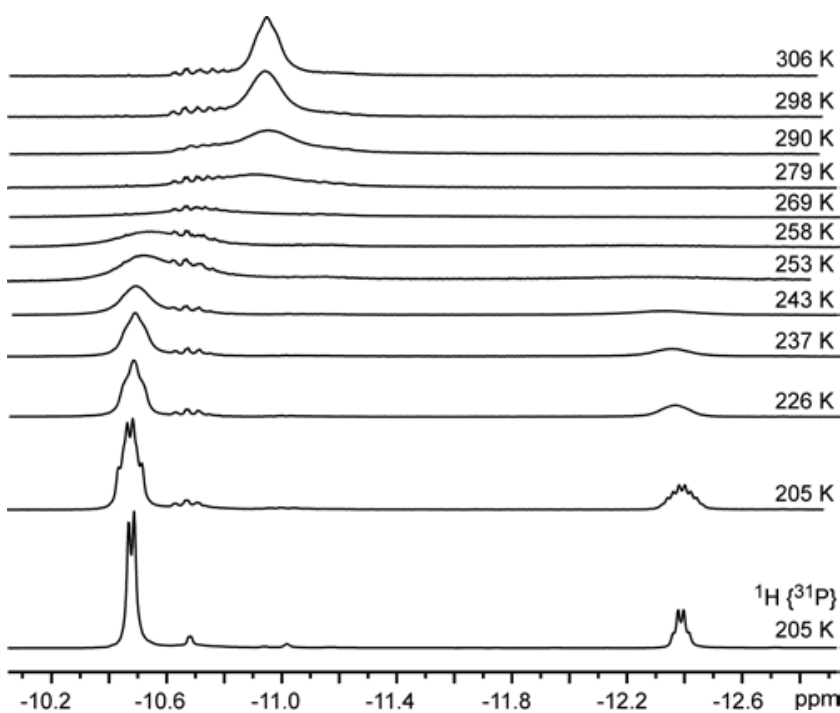

Figure 5. High-field region of the ${ }^{1} \mathrm{H}$ NMR spectrum of the tetrahydride $\mathbf{1 0}$ in THF- $d_{8}$ at different temperatures. The impurity at ca. $\delta-10.69$ corresponds to a signal of complex 9 .

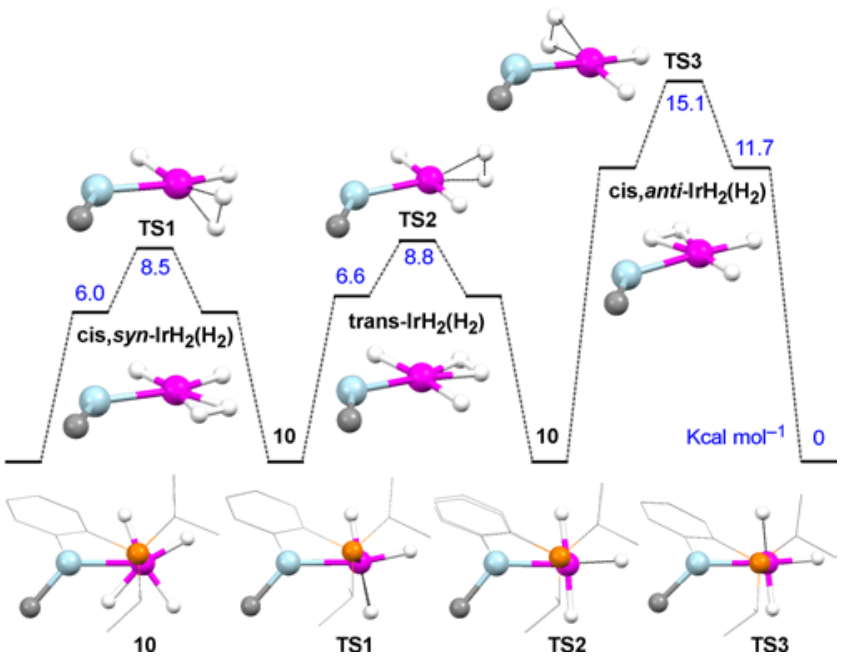

Figure 6. (above) MN15-L calculated free energy ( $\Delta G$, kcal $\mathrm{mol}^{-1}$ ) profile for hydride exchange in 10. (below) View along the 
P...P axis of the structures calculated for $\mathbf{1 0}$ and the transition states.

The easy exchange among three of the hydrides of $\mathbf{1 0}$ could be readily modelled as facile dihydrogen ligand rotations in the dihydride-dihydrogen structures, as shown in Figure 6. In turn, the involvement of the fourth hydride in the exchange was found to be more energy-demanding, in agreement with the experimental observations. The calculated $\Delta H^{\ddagger}$ values for this latter exchange (13.5 (PBE0), 13.4 (mPW1k), and 14.2 (MN15-L) kcal mol ${ }^{-1}$ ) are reasonably close to $\Delta H^{\ddagger}=12.4 \pm 0.4 \mathrm{kcal} \mathrm{mol}^{-1}$ estimated from the experimental rates obtained via line-shape analysis of the ${ }^{1} \mathrm{H}$ NMR hydride signals (see Supporting Information for details).

Free energy of the calculated dihydride-dihydrogen intermedi-

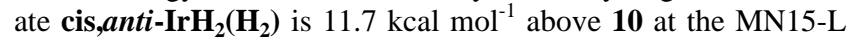
level. This relatively high value and the hindered exchange of the corresponding hydrides in $\mathbf{1 0}$ should be attributed to spatial constraints. As appears from the X-ray structures of this work (none of which includes sterically demanding equatorial ligands), the PSiP pincer ligand prefers a mer configuration with the $\mathrm{P}-\mathrm{Ir}-\mathrm{P}$ angle ranging from $155^{\circ}(\mathbf{8}$ and $\mathbf{9})$ to $163^{\circ}(\mathbf{1}$ and $\mathbf{2})$. The deviation from the exact trans angle $180^{\circ}$ is always at the expense of the space available at the anti face vs. $\mathrm{Si}-\mathrm{Me}$, since the iridium atom is pushed out from the P-Si-P plane towards the syn face. Such a distortion is illustrated at the bottom of Figure 6 for the calculated structure of 10, which in this respect is similar to those of the lowenergy dihydride-dihydrogen minima and the transition states TS1 and TS2. On the contrary, TS3 seems to require more space in the anti face and to this end brings the metal into the P-Si-P plane. This demands several minor bond elongations in the ligand skeleton that add up to give a significant barrier. In favor of such a steric rational, the analogue of $\mathbf{1 0}$ with tert-butyl instead of isopropyl groups at the pincer was reported to display the 3:1 pattern in the ${ }^{1} \mathrm{H}$ NMR hydride region already at room temperature. ${ }^{19}$

Opposite to its distortion into a strictly mer ligand, this PSiP pincer can readily become fac-coordinating. The ease of such transformation is illustrated by the behavior of the anionic trihydride $\left[\mathrm{IrH}_{3}\left\{\kappa P, P, \mathrm{Si}\right.\right.$-Si(Me) $\left.\left.\left(\mathrm{C}_{6} \mathrm{H}_{4}-2-\mathrm{PiPr}_{2}\right)_{2}\right\}\right] \mathrm{Na}$ (11) (Scheme 5), which was prepared from either $\mathbf{1}$ or $\mathbf{1 0}$ as an equilibrium mixture of mer and fac isomers.

\section{Scheme 5}
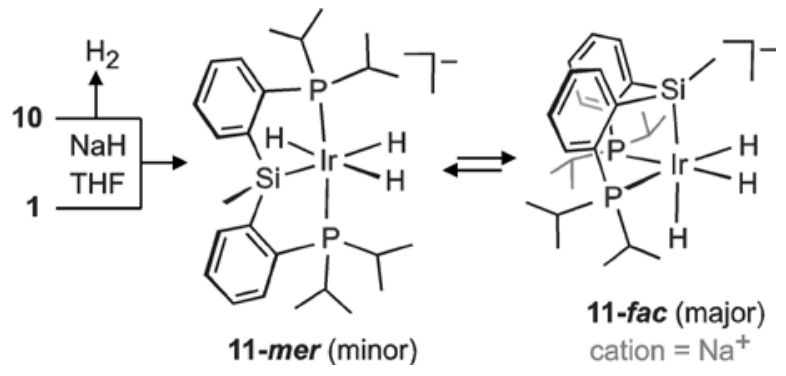

The reaction was observed by NMR to be selective when starting from 10 and one equivalent of $\mathrm{NaH}$, or from 1 and $\mathrm{NaH}$ excess, although only in THF- $d_{8}$ solution. Subsequent manipulations aimed at the precipitation and isolation of the products always led to mixtures containing $\mathbf{1 0}$ and various unidentified complexes as impurities. Yet, isomer 11-fac could be crystallized from a THF solution stored at low temperature, and was characterized by $\mathrm{X}$ ray diffraction (Figure 7). Its structure, featuring three hydride ligands in facial arrangement, agrees with the hydride ${ }^{1} \mathrm{H}$ NMR signals of the major isomer in solution, that correspond to the AMM' part of an AMM'XX' spin system $\left(X={ }^{31} \mathrm{P}\right)$. Simulation of these signals (Figure 8 above) requires cis and trans $J_{\mathrm{HP}}$ coupling constants for each of the chemically equivalent hydrides (108.0 and $20.0 \mathrm{~Hz}$, respectively) and a mutual $J_{\mathrm{PP}}$, coupling of about $10.0 \mathrm{~Hz}$ between the magnetically nonequivalent phosphorus. The latter is consistent with the $\mathrm{P}-\mathrm{Ir}-\mathrm{P}$ angles found in the X-ray structure, in the range $105.12(4)$ to $106.45(4)^{\circ}$. The solid state structure also features contacts between the hydrides and the sodium cations, in the range $2.3-2.6 \AA$ away from the positions assigned to the hydrides, which are likely responsible for the actual dimeric assembly in the solid state. The cations complete their coordination sphere with a molecule of THF, which might account for the importance of this solvent in the reaction.

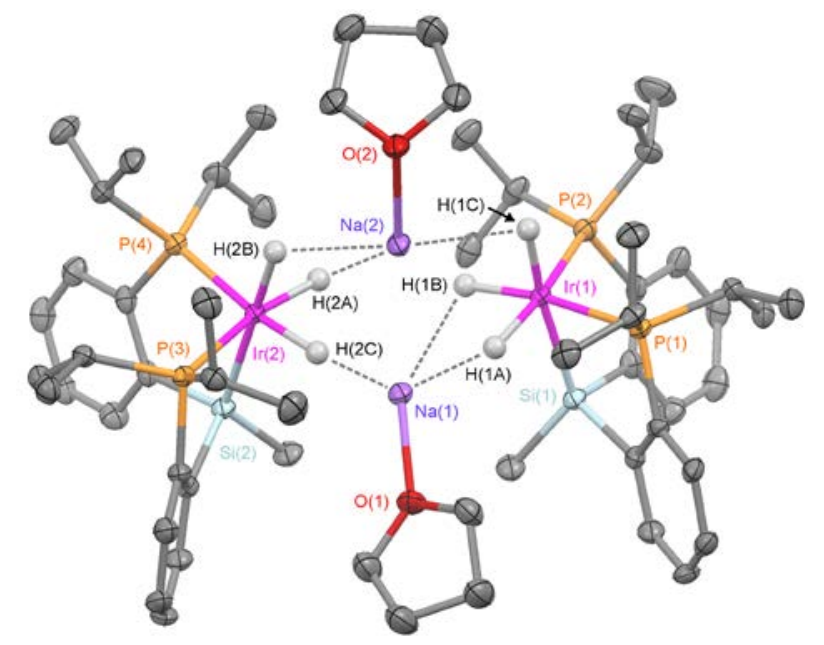

Figure 7. Structure of the fac isomer of complex 11. Only one of the two independent dimer molecules is represented. Ellipsoids for the anisotropic displacement parameters at the 50\% level. Hydrogen atoms except hydrides have been omitted for the sake of clarity. For bond distances and angles, see Supporting Information.

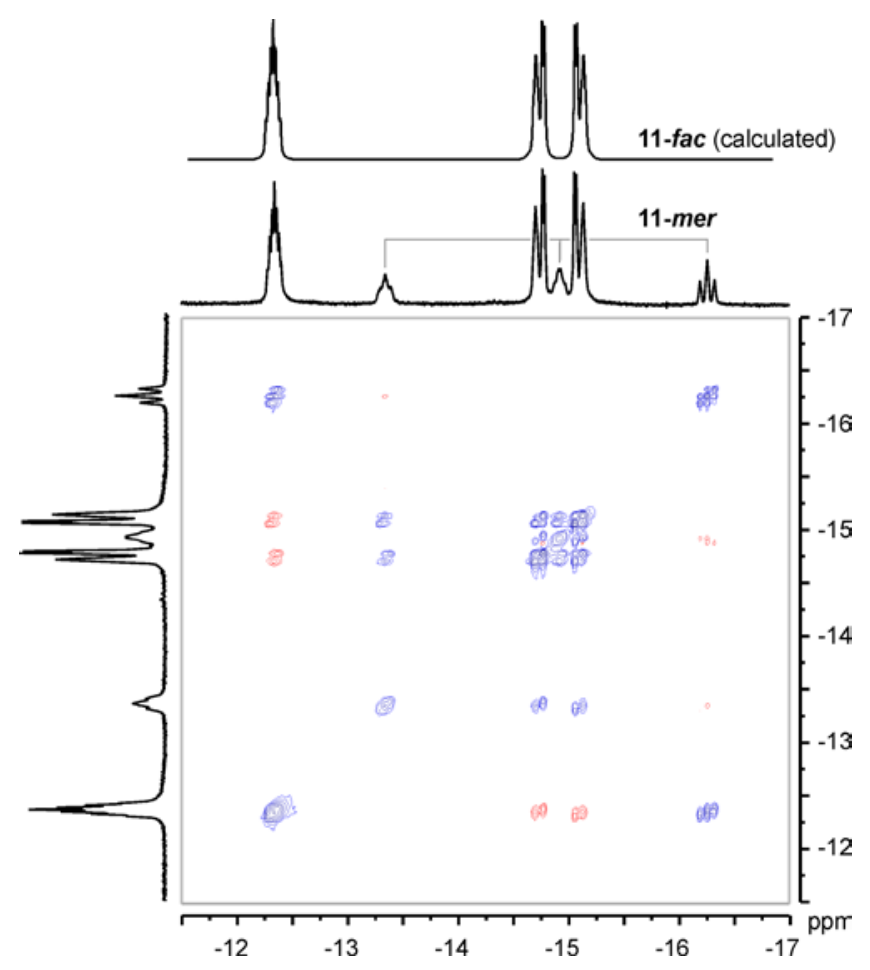

Figure 8. High-field region of the ${ }^{1} \mathrm{H}$ NMR nOesy spectrum of isomers 11 in THF- $d_{8}$ at $250 \mathrm{~K}$. Red cross-peaks denote signal enhancements (nOe) while blue ones correspond to the diagonal 
and signal detractions (saturation transfer). The calculated hydride region of the ${ }^{1} \mathrm{H}$ spectrum of 11-fac is shown on top.

Above $260 \mathrm{~K}$, the NMR signals of $\mathbf{1 1}$ in THF- $d_{8}$ are broadened due to the fast exchange between isomers. The position of the equilibrium also changes with temperature, slightly favoring the mer isomer as the temperature decreases. Experimental equilibrium constants $(K=[11-$ fac $] /[11-m e r])$ were obtained from the integrals of the ${ }^{31} \mathrm{P}\left\{{ }^{1} \mathrm{H}\right\}$ NMR signals in the temperature range 210 to $313 \mathrm{~K}$, to estimate the equilibrium thermodynamic parameters as: $\Delta H^{\circ}=1.3 \pm 0.2 \mathrm{Kcal} \mathrm{mol}^{-1}$ and $\Delta S^{\circ}=7.8 \pm 0.7 \mathrm{cal} \mathrm{K}$ $\mathrm{mol}^{-1}$. In line with what the structure of Figure 7 shows, the significant entropy change suggests a relevant role of the cation and/or the solvent in the stabilization of these anionic complexes, also in solution.

The hydride region of the ${ }^{1} \mathrm{H}$ NMR nOesy spectrum at $250 \mathrm{~K}$ shown in Figure 8 allows assignment of three hydride signals of isomer 11-mer via their mutual nOe effects (in red), and reveals the chemical exchanges among hydrides involved in the mer to $f a c$ isomerization (in blue, out of the diagonal). Noteworthy, the exchange cross-peaks twin the hydride ligands trans to silicon of each isomer (and correspondingly the other remaining four) while there are no intramolecular hydride ligand exchanges. Such an observation renders very unlikely any intramolecular isomerization mechanism, and points to alternatives based on hydride ligand $\left(\mathrm{H}^{-}\right)$dissociations. The rates of isomerization, estimated between 282 and $313 \mathrm{~K}$ from the line-width of the ${ }^{31} \mathrm{P}\left\{{ }^{1} \mathrm{H}\right\}$ NMR signal of 11-fac, lead to the activation parameters: $\Delta H^{\ddagger}=12.0 \pm$ $1.1 \mathrm{Kcal} \mathrm{mol}^{-1}$ and $\Delta S^{\ddagger}=-11 \pm 3 \mathrm{cal} \mathrm{K}^{-1} \mathrm{~mol}^{-1}$. The non-zero activation entropy also seems to discredit intramolecular mechanisms while again suggests that cation and/or solvent may play a role in the intermolecular hydride exchange.

\section{CONCLUDING REMARKS}

Chloride ligand replacement with triflate or tetrafluoroborate in the five-coordinate (PSiP)Ir precursor $\mathbf{1}$ gives access to a variety of hydride derivatives with different charge and different number of hydride ligands. Their structures and reactions confirm the relevance of the silyl group trans influence to define the coordination environments, and the ability of this pincer in the mer coordination mode to discriminate between the two faces of its complexes. In fact, the dynamic behavior in solution observed for the tetrahydride $\mathbf{1 0}$ reveals that the spatial contour of the PSiP framework can condition phenomena as elusive as hydride ligand motions.

\section{EXPERIMENTAL SECTION}

General information. All manipulations were carried out with exclusion of air by using standard Schlenk techniques or in an argon-filled drybox (MBraun). Solvents were obtained from a solvent purification system (MBraun). Deuterated solvents were dried with appropriate drying agents and degassed with argon prior to use. $\mathrm{C}, \mathrm{H}$ and $\mathrm{N}$ analyses were carried out in a PerkinElmer 2400 CHNS/O analyzer. MALDI-TOF MS were obtained in a Bruker Microflex mass spectrometer using DCTB (1,1dicyano-4-terbuthylphenyl-3-methylbutadiene) as matrix. Attenuated total reflection infrared spectra (ATR-IR) of solid samples were run on a Perkin-Elmer Spectrum 100 FT-IR spectrometer. NMR spectra were recorded on Bruker Avance 400 or $300 \mathrm{MHz}$ spectrometers. ${ }^{1} \mathrm{H}(400.13$ or $300.13 \mathrm{MHz})$ and ${ }^{13} \mathrm{C}(100.6$ or 75.5 $\mathrm{MHz}$ ) NMR chemical shifts were measured relative to partially deuterated solvent peaks but are reported in ppm relative to TMS. ${ }^{19} \mathrm{~F}(376.5 \mathrm{MHz}),{ }^{31} \mathrm{P}(162.0$ or $121.5 \mathrm{MHz}),{ }^{11} \mathrm{~B}(96.3 \mathrm{MHz})$ and ${ }^{29} \mathrm{Si}$ (79.5 or $59.6 \mathrm{MHz}$ ) chemical shifts were measured relative to $\mathrm{CFCl}_{3}, \mathrm{H}_{3} \mathrm{PO}_{4}(85 \%), \mathrm{BF}_{3}(\mathrm{OEt})_{2}$ and TMS, respectively. Coupling constants, ${ }^{\mathrm{n}} J$ and ${ }^{\mathrm{n}, \mathrm{m}} N\left(={ }^{\mathrm{n}} J+{ }^{\mathrm{m}} J\right.$ ' for couplings with chemi- cally equivalent but magnetically inequivalent nuclei), are given in hertz. In general, NMR spectral assignments were achieved through ${ }^{1} \mathrm{H}\left\{{ }^{1} \mathrm{H}\right\},{ }^{1} \mathrm{H}$ cosy, ${ }^{1} \mathrm{H}$ nOesy, ${ }^{1} \mathrm{H}\left\{{ }^{31} \mathrm{P}\right\},{ }^{13} \mathrm{C}$ apt, and ${ }^{1} \mathrm{H} /{ }^{13} \mathrm{C}$ hsqc experiments. Unless otherwise indicated, the NMR data are given at room temperature.

Precursor complex 1 was prepared as previously described. ${ }^{19}$ All other reagents were commercial and were used as received. The new complexes described below are air-sensitive in solution and solid state.

Preparation of [IrH $\left\{\kappa O-\mathrm{O}_{3} \mathrm{~S}\left(\mathrm{CF}_{3}\right)\right\}\left\{\kappa P, P, S i-\mathrm{Si}(\mathrm{Me})\left(\mathrm{C}_{6} \mathrm{H}_{4}-2-\right.\right.$ $\left.\mathbf{P i P r}_{2}\right)_{2}$ \}] (2). A solution of $\mathbf{1}$ (200 mg, $\left.0.30 \mathrm{mmol}\right)$ in $\mathrm{CH}_{2} \mathrm{Cl}_{2}$ (10 $\mathrm{mL})$ was treated with methyl triflate $(36 \mu \mathrm{L}, 0.32 \mathrm{mmol})$ and stirred at room temperature for $24 \mathrm{~h}$. Concentration of the resulting solution to ca. $0.5 \mathrm{~mL}$ and addition of hexane $(3 \mathrm{~mL})$ produced a pale yellow solid, which was separated by decantation, and dried in vacuo: yield $181 \mathrm{mg}$ (78\%). Anal. Cald. for $\mathrm{C}_{26} \mathrm{H}_{40} \mathrm{~F}_{3} \mathrm{O}_{3} \mathrm{P}_{2}$ SSiIr: C, 40.46; $\mathrm{H}, 5.22$. Found: C, 40.83; $\mathrm{H}, 5.24$. ${ }^{1} \mathrm{H}$ NMR $\left(\mathrm{CD}_{2} \mathrm{Cl}_{2}\right): \delta-29.52\left(\mathrm{t},{ }^{2} J_{\mathrm{HP}}=14.9,1 \mathrm{H}, \mathrm{IrH}\right), 0.56(\mathrm{~s}$, $\left.3 \mathrm{H}, \mathrm{SiCH}_{3}\right), 0.95\left(\mathrm{dvt},{ }^{3} J_{\mathrm{HH}}=8.7,{ }^{3,5} N_{\mathrm{HP}}=15.8,6 \mathrm{H}, \mathrm{PCHCH}_{3}\right.$ ), $1.06\left(\mathrm{dvt},{ }^{3} J_{\mathrm{HH}}=10.3,{ }^{3,5} N_{\mathrm{HP}}=16.2,6 \mathrm{H}, \mathrm{PCHCH}_{3}\right), 1.30(\mathrm{dvt}$, $\left.{ }^{3} J_{\mathrm{HH}}=5.6,{ }^{3,5} N_{\mathrm{HP}}=12.4,6 \mathrm{H}, \mathrm{PCHCH}_{3}\right), 1.42\left(\mathrm{dvt},{ }^{3} J_{\mathrm{HH}}=9.8\right.$, ${ }^{3,5} N_{\mathrm{HP}}=15.6,6 \mathrm{H}, \mathrm{PCHCH}_{3}$ ), 2.90, 3.20 (both m, $2 \mathrm{H}$ each, $\mathrm{PCHCH}_{3}$ ), 7.38, 7.46 (both dd, ${ }^{3} J_{\mathrm{HH}}={ }^{3} J_{\mathrm{HH}} \approx 7.3,2 \mathrm{H}$ each, $\mathrm{CH}$ ), $7.58(\mathrm{~m}, 2 \mathrm{H}, \mathrm{CH}), 8.06\left(\mathrm{~d},{ }^{3} J_{\mathrm{HH}}=7.3,2 \mathrm{H}, \mathrm{CH}\right) .{ }^{19} \mathrm{~F}$ NMR $\left(\mathrm{CD}_{2} \mathrm{Cl}_{2}\right): \delta-77.49(\mathrm{~s}) .{ }^{31} \mathrm{P}\left\{{ }^{1} \mathrm{H}\right\}$ NMR $\left(\mathrm{CD}_{2} \mathrm{Cl}_{2}\right): \delta 69.60(\mathrm{~s})$. ${ }^{13} \mathrm{C}\left\{{ }^{1} \mathrm{H}\right\}$ NMR $\left(\mathrm{CD}_{2} \mathrm{Cl}_{2}\right): \delta 2.63\left(\mathrm{~s}, \mathrm{SiCH}_{3}\right), 17.99\left(\mathrm{vt},{ }^{2,4} N_{\mathrm{CP}}=\right.$ 3.2, $\mathrm{PCHCH}_{3}$ ), 18.91 (vt, ${ }^{2,4} N_{\mathrm{CP}}=6.4, \mathrm{PCHCH}_{3}$ ), 19.73 (vt, ${ }^{2,4} N_{\mathrm{CP}}$ $=4.4, \mathrm{PCHCH}_{3}$ ), $20.53\left(\mathrm{vt},{ }^{2,4} N_{\mathrm{CP}}=2.3, \mathrm{PCHCH}_{3}\right.$ ), 26.05 (vt, $\left.{ }^{1,3} N_{\mathrm{CP}}=24.6, \mathrm{PCHCH}_{3}\right), 26.30\left(\mathrm{vt},{ }^{1,3} N_{\mathrm{CP}}=31.8, \mathrm{PCHCH}_{3}\right)$, $120.84\left(\mathrm{q},{ }^{1} J_{\mathrm{CF}}=319.3, \mathrm{SO}_{3} \mathrm{CF}_{3}\right), 128.42\left(\mathrm{vt},{ }^{3,5} N_{\mathrm{CP}}=7.2, \mathrm{CH}\right)$, 130.23 (s, CH), 131.25 (vt, $\left.{ }^{2,4} N_{\mathrm{CP}}=5.3, \mathrm{CH}\right), 131.85$ (vt, ${ }^{3,4} N_{\mathrm{CP}}=$ $17.8, \mathrm{CH}), 140.16\left(\mathrm{vt},{ }^{1,3} N_{\mathrm{CP}}=53.8, \mathrm{C}\right), 155.56\left(\mathrm{vt},{ }^{2,3} N_{\mathrm{CP}}=40.3\right.$, C), ${ }^{29} \mathrm{Si}\left\{{ }^{1} \mathrm{H}\right\}$ NMR $\left(\mathrm{CD}_{2} \mathrm{Cl}_{2}\right): \delta 8.94$ (s).

[IrH $\left.\left\{\kappa P, P, S i-S i(M e)\left(C_{6} \mathrm{H}_{4}-2-\mathrm{PiPr}_{2}\right)_{2}\right\}\left(\mathrm{OH}_{2}\right)_{2}\right]\left(\mathrm{CF}_{3} \mathrm{SO}_{3}\right)$ (3). A solution of $2(12.0 \mathrm{mg}, 0.015 \mathrm{mmol})$ in $0.5 \mathrm{~mL}$ of $\mathrm{CD}_{2} \mathrm{Cl}_{2}$ was treated with $1 \mu \mathrm{L}$ of $\mathrm{H}_{2} \mathrm{O}$. The NMR at $173 \mathrm{~K}$ spectra revealed a mixture of 2 and a new complex, 3, in relative proportion 1:6. Partial data for $3:{ }^{1} \mathrm{H}$ NMR $\left(\mathrm{CD}_{2} \mathrm{Cl}_{2}, 173 \mathrm{~K}\right): \delta-28.86$ (brt, ${ }^{2} J_{\mathrm{HP}} \approx$ 16.0, 1H, IrH), 0.32 (s, 3H, $\mathrm{SiCH}_{3}$ ), 0.75 and 1.16 (both br, $12 \mathrm{H}$ each, $\mathrm{PCHCH}_{3}$ ), 2.69 and 3.11 (both br, $2 \mathrm{H}$ each, $\mathrm{PCHCH}_{3}$ ), 4.30 and 4.89 (both br, $2 \mathrm{H}$ each, $\mathrm{IrOH}_{2}$ ), 7.30, 7.39 and 7.50 (all m, 2H each, CH), $8.02\left(\mathrm{~d},{ }^{3} J_{\mathrm{HH}}=7.0,2 \mathrm{H}, \mathrm{CH}\right) .{ }^{19} \mathrm{~F} \mathrm{NMR}\left(\mathrm{CD}_{2} \mathrm{Cl}_{2}, 233\right.$ $\mathrm{K}): \delta-78.98(\mathrm{~s}) .{ }^{31} \mathrm{P}\left\{{ }^{1} \mathrm{H}\right\}\left(\mathrm{CD}_{2} \mathrm{Cl}_{2}, 233 \mathrm{~K}\right): \delta 54.46(\mathrm{~s})$.

\section{Preparation of [IrH\{KP,P,Si-Si(Me) $\left(\mathrm{C}_{6} \mathrm{H}_{4}-2\right.$ -} $\left.\left.\left.\mathrm{PiPr}_{2}\right)_{2}\right\}(\mathrm{NCMe})_{2}\right]\left(\mathrm{SO}_{3} \mathrm{CF}_{3}\right)$ (4). A solution of 1 (200 mg, 0.30 $\mathrm{mmol})$ in acetone/acetonitrile $(5 / 1 \mathrm{~mL})$ was treated with silver triflate $(77.1 \mathrm{mg}, 0.30 \mathrm{mmol}$ ) and stirred for $24 \mathrm{~h}$ in the dark. The resulting suspension was filtered through Celite to remove the insoluble silver chloride and concentrated to ca. $0.5 \mathrm{~mL}$. Addition of diethyl ether $(3 \mathrm{~mL})$ produced a pale yellow solid, which was separated by decantation, washed with diethyl ether, and dried in vacuo: yield $172 \mathrm{mg}$ (67 \%). Anal. Cald. for $\mathrm{C}_{36} \mathrm{H}_{46} \mathrm{~F}_{3} \mathrm{~N}_{2} \mathrm{O}_{3} \mathrm{P}_{2}$ SSiIr: C, 42.20; H, 5.43; N, 3.28. Found: C, 41.90; H, 5.02; N, 3.48. ${ }^{1} \mathrm{H}$ NMR $\left(\mathrm{CDCl}_{3}\right): \delta-21.35\left(\mathrm{t},{ }^{2} J_{\mathrm{HP}}=\right.$ $16.5,1 \mathrm{H}, \mathrm{IrH}), 0.33\left(\mathrm{~s}, 3 \mathrm{H}, \mathrm{SiCH}_{3}\right), 1.04\left(\mathrm{dvt},{ }^{3} J_{\mathrm{HH}}=7.5,{ }^{3,5} N_{\mathrm{HP}}=\right.$ 14.7, $6 \mathrm{H}, \mathrm{PCHCH}), 1.09\left(\mathrm{dvt},{ }^{3} J_{\mathrm{HH}}=7.3,{ }^{3,5} N_{\mathrm{HP}}=14.3,6 \mathrm{H}\right.$, $\mathrm{PCHCH}_{3}$ ), 1.21 (m, 12H, PCHCH $\mathrm{H}_{3}, 2.46$ (brs, 3H, $\mathrm{NCCH}_{3}$ ), 2.51 $\left(\mathrm{s}, 3 \mathrm{H}, \mathrm{NCCH}_{3}\right), 2.80\left(\mathrm{~m}, 4 \mathrm{H}, \mathrm{PCHCH}\right.$ ), 7.33, 7.43 (both dd, ${ }^{3} J_{\mathrm{HH}}$ $={ }^{3} J_{\mathrm{HH}} \approx 7.3,2 \mathrm{H}$ each, CH), $7.58(\mathrm{~m}, 2 \mathrm{H}, \mathrm{CH}), 8.04\left(\mathrm{~d},{ }^{3} J_{\mathrm{HH}}=\right.$ 7.3, 2H, CH). ${ }^{19} \mathrm{~F}$ NMR $\left(\mathrm{CDCl}_{3}\right): \delta-78.13$ (s). ${ }^{31} \mathrm{P}\left\{{ }^{1} \mathrm{H}\right\}$ NMR $\left(\mathrm{CDCl}_{3}\right): \delta 48.30(\mathrm{~s}) .{ }^{13} \mathrm{C}\left\{{ }^{1} \mathrm{H}\right\} \mathrm{NMR}\left(\mathrm{CDCl}_{3}\right): \delta 3.30,3.59$ (both s, $\left.\mathrm{NCCH}_{3}\right), 3.88\left(\mathrm{~s}, \mathrm{SiCH}_{3}\right), 18.40\left(\mathrm{~s}, \mathrm{PCHCH}_{3}\right), 18.47$ (vt, ${ }^{2,4} N_{\mathrm{CP}}=$ 2.3, $\mathrm{PCHCH}_{3}$ ), 18.63 (vt, ${ }^{2,4} N_{\mathrm{CP}}=3.9, \mathrm{PCHCH}_{3}$ ), 19.45 (s, $\left.\mathrm{PCHCH}_{3}\right), 26.87\left(\mathrm{vt},{ }^{1,3} N_{\mathrm{CP}}=32.0, \mathrm{PCHCH}_{3}\right), 27.68\left(\mathrm{vt},{ }^{1,3} N_{\mathrm{CP}}=\right.$ 25.1, $\mathrm{PCHCH}_{3}$ ), 123.20 (brs, $\mathrm{NCCH}_{3}$ ), 128.15 (vt, ${ }^{3,5} N_{\mathrm{CP}}=7.5$, 
$\mathrm{CH}$ ), 129.43 (vt, $\left.{ }^{2,4} N_{\mathrm{CP}}=5.9, \mathrm{CH}\right), 129.98$ (s, CH), 132.38 (vt, $\left.{ }^{3,4} N_{\mathrm{CP}}=18.8, \mathrm{CH}\right), 141.69\left(\mathrm{vt},{ }^{1,3} N_{\mathrm{CP}}=57.2, \mathrm{C}\right), 156.44\left(\mathrm{vt},{ }^{2,3} N_{\mathrm{CP}}\right.$ $=41.3, \mathrm{C}),{ }^{29} \mathrm{Si}\left\{{ }^{1} \mathrm{H}\right\} \mathrm{NMR}\left(\mathrm{CDCl}_{3}\right): \delta 19.87\left(\mathrm{t},{ }^{3} J_{\mathrm{SiP}}=3.9\right)$.

Preparation

of

[IrH $\left\{\kappa P, P, S i-S i(M e)\left(\mathrm{C}_{6} \mathrm{H}_{4}-2\right.\right.$ $\left.\left.\left.\mathrm{PiPr}_{2}\right)_{2}\right\}(\mathrm{CO})_{2}\right]\left(\mathrm{SO}_{3} \mathrm{CF}_{3}\right)$ (5). Carbon monoxide was slowly bubbled for $1 \mathrm{~min}$ through a solution of $2(123 \mathrm{mg}, 0.16 \mathrm{mmol})$ in $\mathrm{CH}_{2} \mathrm{Cl}_{2}(10 \mathrm{~mL})$. The resulting solution was taken to dryness, and the residue was treated with diethyl ether to give a white solid. The solid was separated by decantation, washed with diethyl ether and dried in vacuo: yield $119 \mathrm{mg}(90 \%)$. IR $\left(\mathrm{cm}^{-1}\right)$ : $2140 \mathrm{v}(\mathrm{IrH})$, $2079 v(\mathrm{CO}), 2028 v(\mathrm{CO}), 1258 v\left(\mathrm{SO}_{3}\right)$. Anal. Cald. for $\mathrm{C}_{28} \mathrm{H}_{40} \mathrm{~F}_{3} \mathrm{O}_{5} \mathrm{P}_{2}$ SSiIr: C, 40.62; H, 4.87. Found: C, 41.02; H, 5.32. ${ }^{1} \mathrm{H}$ NMR $\left(\mathrm{CD}_{2} \mathrm{Cl}_{2}\right): \delta-11.66\left(\mathrm{t},{ }^{2} J_{\mathrm{HP}}=15.0,1 \mathrm{H}, \mathrm{IrH}\right), 0.75(\mathrm{~s}$, $3 \mathrm{H}, \mathrm{SiCH}_{3}$ ), 1.03, 1.10 (both dvt, ${ }^{3} J_{\mathrm{HH}}=6.9,{ }^{3,5} N_{\mathrm{HP}}=17.1,6 \mathrm{H}$ each, $\mathrm{PCHCH}_{3}$ ), 1.24, 1.29 (both $\mathrm{m},{ }^{3} J_{\mathrm{HH}}=6.9,{ }^{3,5} N_{\mathrm{HP}} \approx 15.4,6 \mathrm{H}$ each, $\mathrm{PCHCH}_{3}$ ), 2.79, 2.95 (both $\mathrm{m}, 2 \mathrm{H}$ each, $\mathrm{PCHCH}_{3}$ ), 7.58, 7.67 (both dd, ${ }^{3} J_{\mathrm{HH}}={ }^{3} J_{\mathrm{HH}} \approx 7.2,2 \mathrm{H}$ each, $\left.\mathrm{CH}\right), 7.74(\mathrm{~m}, 2 \mathrm{H}$, $\mathrm{CH}), 8.16\left(\mathrm{~d},{ }^{3} J_{\mathrm{HH}}=7.2,2 \mathrm{H}, \mathrm{CH}\right) .{ }^{19} \mathrm{~F} \mathrm{NMR}\left(\mathrm{CDCl}_{3}\right): \delta-78.13$ (s). ${ }^{31} \mathrm{P}\left\{{ }^{1} \mathrm{H}\right\}$ NMR $\left(\mathrm{CD}_{2} \mathrm{Cl}_{2}\right): \delta 56.18(\mathrm{~s}) .{ }^{13} \mathrm{C}\left\{{ }^{1} \mathrm{H}\right\}$ NMR $\left(\mathrm{CD}_{2} \mathrm{Cl}_{2}\right)$ : $\delta 3.55\left(\mathrm{~s}, \mathrm{SiCH}_{3}\right), 18.61,18.80,19.77$ (all s, $\mathrm{PCHCH}_{3}$ ), 19.79 (vt, ${ }^{2,4} N_{\mathrm{CP}}=2.9, \mathrm{PCHCH}$ ), $30.10\left(\mathrm{vt},{ }^{1,3} N_{\mathrm{CP}}=29.2, \mathrm{PCHCH}_{3}\right), 30.33$ (vt, $\left.{ }^{1,3} N_{\mathrm{CP}}=35.6, \mathrm{PCHCH}_{3}\right), 130.42\left(\mathrm{vt},{ }^{2,4} N_{\mathrm{CP}}=7.8, \mathrm{CH}\right), 130.83$ (vt, $\left.{ }^{4,5} N_{\mathrm{CP}}=8.8, \mathrm{CH}\right), 132.65\left(\mathrm{vt},{ }^{3,5} N_{\mathrm{CP}}=2.1, \mathrm{CH}\right), 134.07$ (vt, $\left.{ }^{3,4} N_{\mathrm{CP}}=19.1, \mathrm{CH}\right), 138.43\left(\mathrm{vt},{ }^{1,3} N_{\mathrm{CP}}=62.3, \mathrm{C}\right), 153.17\left(\mathrm{vt},{ }^{2,3} N_{\mathrm{CP}}\right.$ $=37.0, \mathrm{C}), 166.46\left(\mathrm{t},{ }^{2} J_{\mathrm{CP}}=6.1, \mathrm{CO}\right), 171.10\left(\mathrm{t},{ }^{2} J_{\mathrm{CP}}=4.6, \mathrm{CO}\right)$. ${ }^{29} \mathrm{Si}\left\{{ }^{1} \mathrm{H}\right\}$ NMR $\left(\mathrm{CD}_{2} \mathrm{Cl}_{2}\right): \delta 32.86\left(\mathrm{t},{ }^{3} J_{\mathrm{SiP}}=2.1\right)$.

$\left[\mathrm{IrH}\left\{\kappa \mathrm{O}-\mathrm{O}_{3} \mathrm{~S}\left(\mathrm{CF}_{3}\right)\right\}\left\{\kappa P, P, \mathrm{Si}-\mathrm{Si}(\mathrm{Me})\left(\mathrm{C}_{6} \mathrm{H}_{4}-2-\mathrm{PiPr}_{2}\right)_{2}\right\}\left(\eta^{2}-\mathrm{H}_{2}\right)\right]$ (6). A solution of $2(12.0 \mathrm{mg}, 0.015 \mathrm{mmol})$ in $0.5 \mathrm{~mL}$ of $\mathrm{CD}_{2} \mathrm{Cl}_{2}$ contained in a PTFE-valved NMR tube was frozen. Then, the argon inside the tube was evacuated and the tube was filled with hydrogen (1 bar) and sealed. At $233 \mathrm{~K}$, the resulting mixture was observed by NMR to contain 2 together with a new complex $\mathbf{6}$, in relative proportion 3:5. Partial data for 6: ${ }^{1} \mathrm{H}$ NMR $\left(\mathrm{CD}_{2} \mathrm{Cl}_{2}, 233\right.$ $\mathrm{K}): \delta-12.26\left(\mathrm{t},{ }^{2} J_{\mathrm{HP}}=13.4,1 \mathrm{H}, \mathrm{IrH}\right),-1.65\left(\mathrm{br}, 2 \mathrm{H}, \operatorname{Ir}\left(\mathrm{H}_{2}\right)\right), 0.24$ (s, 3H, $\mathrm{SiCH}_{3}$ ), 7.36, 7.45 and 7.69 (all $\mathrm{m}, 2 \mathrm{H}$ each, $\left.\mathrm{CH}\right), 7.96$ (d, $\left.{ }^{3} J_{\mathrm{HH}}=7.1,2 \mathrm{H}, \mathrm{CH}\right) .{ }^{19} \mathrm{~F}$ NMR $\left(\mathrm{CD}_{2} \mathrm{Cl}_{2}, 233 \mathrm{~K}\right): \delta-77.37(\mathrm{~s})$. ${ }^{31} \mathrm{P}\left\{{ }^{1} \mathrm{H}\right\}\left(\mathrm{CD}_{2} \mathrm{Cl}_{2}, 233 \mathrm{~K}\right): \delta 59.23(\mathrm{~s}) .{ }^{29} \mathrm{Si}\left\{{ }^{1} \mathrm{H}\right\}$ NMR $\left(\mathrm{CD}_{2} \mathrm{Cl}_{2}\right.$, $233 \mathrm{~K}): \delta 12.06(\mathrm{~s})$.

Preparation of $\left[\operatorname{IrH}\left(\kappa^{2} H-H_{2} B_{2}\right)\left\{\kappa P, P, S i-S i(M e)\left(C_{6} H_{4}-2-\right.\right.\right.$ $\left.\mathbf{P i P r}_{2}\right)_{2}$ \}] (7). A solution of $\mathbf{1}(296 \mathrm{mg}, 0.45 \mathrm{mmol})$ and $\mathrm{NaBH}_{4}$ (88.7 $\mathrm{mg}, 2.25 \mathrm{mmol}$ ) in $10 \mathrm{~mL}$ of THF was stirred under reflux for $4 \mathrm{~h}$. The solution was filtered through Celite, dried in vacuo, re-dissolved in toluene and filtered again. The resulting solution was concentrated to ca. $0.5 \mathrm{~mL}$ and treated with hexane to obtain a pale yellow solid. The solid was separated by decantation, washed with hexane, and dried in vacuo: yield $275 \mathrm{mg}$ (96\%). Anal. Cald. for $\mathrm{C}_{25} \mathrm{H}_{44} \mathrm{BP}_{2}$ SiIr: C, 47.09; H, 6.96. Found: C, 46.65; H, 7.00. ${ }^{1} \mathrm{H}$ NMR $\left(\mathrm{C}_{6} \mathrm{D}_{6}\right): \delta-17.89\left(\mathrm{dt},{ }^{2} J_{\mathrm{HP}}=15.5,{ }^{2} J_{\mathrm{HH}}=\right.$ $8.1,1 \mathrm{H}, \mathrm{IrH}),-7.11,-3.91$ (both br, $1 \mathrm{H}$ each, $\operatorname{Ir} \mathrm{H}_{2} \mathrm{BH}_{2}$ ), 0.70 (dvt, $\left.{ }^{3} J_{\mathrm{HH}}=8.0,{ }^{3,5} N_{\mathrm{HP}}=15.0,6 \mathrm{H}, \mathrm{PCHCH}_{3}\right), 0.84$ (s, 3H, $\mathrm{SiCH}_{3}$ ), $1.02\left(\mathrm{dvt},{ }^{3} J_{\mathrm{HH}}=7.2,{ }^{3,5} N_{\mathrm{HP}}=14.6,6 \mathrm{H}, \mathrm{PCHCH}_{3}\right), 1.06\left(\mathrm{dvt},{ }^{3} J_{\mathrm{HH}}\right.$ $\left.=7.8,{ }^{3,5} N_{\mathrm{HP}}=17.0,6 \mathrm{H}, \mathrm{PCHCH}{ }_{3}\right), 1.27\left(\mathrm{dvt},{ }^{3} J_{\mathrm{HH}}=8.5,{ }^{3,5} N_{\mathrm{HP}}=\right.$ 15.5, 6H, PCHCH$H_{3}$ ), 2.41, 277 (both $\mathrm{m}, 2 \mathrm{H}$ each, $\mathrm{PCHCH}_{3}$ ), 7.09, 7.22 (both dd, ${ }^{3} J_{\mathrm{HH}}={ }^{3} J_{\mathrm{HH}} \approx 7.3,2 \mathrm{H}$ each, $\left.\mathrm{CH}\right), 7.34(\mathrm{~m}, 2 \mathrm{H}$, $\mathrm{CH}), 7.60$ (br, $\left.2 \mathrm{H}, \mathrm{IrH}_{2} \mathrm{~B} \mathrm{H}_{2}\right), 8.08\left(\mathrm{~d},{ }^{3} J_{\mathrm{HH}}=7.3,2 \mathrm{H}, \mathrm{CH}\right)$. ${ }^{31} \mathrm{P}\left\{{ }^{1} \mathrm{H}\right\} \operatorname{NMR}\left(\mathrm{C}_{6} \mathrm{D}_{6}\right): \delta 60.98(\mathrm{~s}) .{ }^{11} \mathrm{~B}\left\{{ }^{1} \mathrm{H}\right\} \operatorname{NMR}\left(\mathrm{C}_{6} \mathrm{D}_{6}\right): \delta 10.95$ (brs), ${ }^{13} \mathrm{C}\left\{{ }^{1} \mathrm{H}\right\} \operatorname{NMR}\left(\mathrm{C}_{6} \mathrm{D}_{6}\right): \delta 6.89\left(\mathrm{~s}, \mathrm{SiCH}_{3}\right), 16.46\left(\mathrm{vt},{ }^{2,4} N_{\mathrm{CP}}=\right.$ 2.8, $\mathrm{PCHCH}_{3}$ ), 17.59 (vt, ${ }^{2,4} N_{\mathrm{CP}}=4.8, \mathrm{PCHCH}_{3}$ ), 20.12 (vt, ${ }^{2,4} N_{\mathrm{CP}}$ $=4.5, \mathrm{PCHCH}_{3}$ ), $20.42\left(\mathrm{vt},{ }^{2,4} N_{\mathrm{CP}}=3.4, \mathrm{PCHCH}_{3}\right), 24.03$ (vt, $\left.{ }^{1,3} N_{\mathrm{CP}}=25.3, \mathrm{PCHCH}_{3}\right), 24.11\left(\mathrm{vt},{ }^{1,3} N_{\mathrm{CP}}=32.7, \mathrm{PCHCH}_{3}\right)$, 127.19 (vt, $\left.{ }^{3,5} N_{\mathrm{CP}}=7.2, \mathrm{CH}\right), 129.64(\mathrm{~s}, \mathrm{CH}), 130.24$ (vt, ${ }^{2,4} N_{\mathrm{CP}}=$ $5.5, \mathrm{CH}), 132.65\left(\mathrm{vt},{ }^{3,4} N_{\mathrm{CP}}=18.8, \mathrm{CH}\right), 142.72\left(\mathrm{vt},{ }^{1,3} N_{\mathrm{CP}}=54.3\right.$, C), $159.32\left(\mathrm{vt},{ }^{2,4} N_{\mathrm{CP}}=42.0, \mathrm{C}\right),{ }^{29} \mathrm{Si}\left\{{ }^{1} \mathrm{H}\right\} \mathrm{NMR}\left(\mathrm{C}_{6} \mathrm{D}_{6}\right): \delta 26.45$ $\left(\mathrm{t},{ }^{3} J_{\mathrm{SiP}}=2.9\right)$. The crystals used in the X-ray diffraction experiment were obtained from a hexane solution stored at $253 \mathrm{~K}$.
Preparation of $\left[\left(\mu: \kappa^{2} H, \kappa^{2} H-B H_{4}\right)\left[\operatorname{IrH}\left\{\kappa P, P, S i-S i(M e)\left(C_{6} \mathrm{H}_{4-}\right.\right.\right.\right.$ 2-PiPr $\left.\left.\left.)_{2}\right\}\right]_{2}\right]\left(\mathbf{B F}_{4}\right)(\mathbf{8})$. A commercial solution of tetrafluoroboric acid in diethyl ether ( $54 \%, 19 \mu \mathrm{L}, 0.14 \mathrm{mmol}$ ) was added dropwise into a solution of $7(174 \mathrm{mg}, 0.27 \mathrm{mmol})$ in $10 \mathrm{~mL}$ of $\mathrm{CH}_{2} \mathrm{Cl}_{2}$. The mixture was stirred for $2 \mathrm{~h}$, concentrated to ca. 0.5 $\mathrm{mL}$, and treated with dry diethyl ether to obtain a pale yellow solid. The solid was separated by decantation, washed with diethyl ether, and dried in vacuo: yield $87.0 \mathrm{mg}$ (47\%). The microanalysis data and NMR spectra of the bulk samples indicate the presence of various minor impurities which could not be removed by recrystallization. Anal. Cald. for $\mathrm{C}_{50} \mathrm{H}_{84} \mathrm{~B}_{2} \mathrm{~F}_{4} \mathrm{P}_{4} \mathrm{Si}_{2} \mathrm{Ir}_{2}$ : C, 44.57; $\mathrm{H}$, 6.28. Found: C, 44.09; H, 5.83. ${ }^{1} \mathrm{H}$ NMR $\left(\mathrm{CDCl}_{3}\right): \delta-16.97(\mathrm{dd}$, $\left.{ }^{2} J_{\mathrm{HP}} \approx 17.3,{ }^{2} J_{\mathrm{HH}}=4.5,2 \mathrm{H}, \mathrm{IrH}\right),-3.57,-3.28$ (both vbr, $2 \mathrm{H}$ each, $\mathrm{H}_{2} \mathrm{BH}_{2}$ ), $0.73\left(\mathrm{~s}, 6 \mathrm{H}, \mathrm{SiCH}_{3}\right.$ ), 0.76, 0.83 (both $\mathrm{m},{ }^{3} J_{\mathrm{HH}} \approx 6.7,6 \mathrm{H}$ each, $\mathrm{PCHCH}_{3}$ ), 0.92, 0.96 (both $\mathrm{m},{ }^{3} J_{\mathrm{HH}} \approx 7.1,6 \mathrm{H}$ each, $\mathrm{PCHCH}_{3}$ ), 1.23, 1.27, 1.29, 1.35 (all $\mathrm{m},{ }^{3} J_{\mathrm{HH}} \approx 6.7,6 \mathrm{H}$ each, $\mathrm{PCHCH}_{3}$ ), 2.54, 2.62, 2.81, 2.89 (all m, 2H each, $\mathrm{PCHCH}_{3}$ ), 7.43, 7.52, 7.60 (all m, 4H each, $\mathrm{CH}$ ), 8.11 (d, $\left.{ }^{3} \mathrm{~J}_{\mathrm{HH}} \approx 7.4,4 \mathrm{H}, \mathrm{CH}\right) .{ }^{19} \mathrm{~F}$ NMR $\left(\mathrm{CD}_{2} \mathrm{Cl}_{2}\right): \delta-152.82(\mathrm{br}) .{ }^{31} \mathrm{P}\left\{{ }^{1} \mathrm{H}\right\}$ NMR $\left(\mathrm{CD}_{2} \mathrm{Cl}_{2}\right): \delta 57.57$ $\left(\mathrm{AB}\right.$ spin system $\left.\delta_{\mathrm{A}}=59.70, \delta_{\mathrm{B}}=55.43,{ }^{2} J_{\mathrm{AB}}=261.9\right) .{ }^{11} \mathrm{~B}\left\{{ }^{1} \mathrm{H}\right\}$ NMR $\left(\mathrm{CD}_{2} \mathrm{Cl}_{2}\right): \delta-1.21\left(\mathrm{~s}, \mathrm{BF}_{4}\right), 17.19\left(\mathrm{br}, \mathrm{BH}_{4}\right) \cdot{ }^{13} \mathrm{C}\left\{{ }^{1} \mathrm{H}\right\}$ NMR $\left(\mathrm{CDCl}_{3}\right): \delta 7.41\left(\mathrm{~s}, \mathrm{SiCH}_{3}\right), 17.10\left(\mathrm{~d},{ }^{2} J_{\mathrm{CP}}=3.6, \mathrm{PCHCH}_{3}\right), 17.25$ $\left(\mathrm{d},{ }^{2} J_{\mathrm{CP}}=3.2, \mathrm{PCHCH}_{3}\right.$ ), 19.47, 19.63 (both dd, ${ }^{2} J_{\mathrm{CP}} \approx 3.6,{ }^{4} J_{\mathrm{CP}}=$ 1.6, $\mathrm{PCHCH}_{3}$ ), 19.95, 20.10 (both s, $\mathrm{PCHCH}_{3}$ ), 20.33, 21.43 (both d, ${ }^{2} J_{\mathrm{CP}} \approx 1.7, \mathrm{PCHCH}_{3}$ ), 24.96, 25.09 (both dd, ${ }^{1} J_{\mathrm{CP}} \approx 24.8,{ }^{3} J_{\mathrm{CP}} \approx$ 12.3, $\mathrm{PCHCH}_{3}$ ), 26.47, 26.99 (both dd, ${ }^{1} J_{\mathrm{CP}} \approx 16.8,{ }^{3} J_{\mathrm{CP}} \approx 8.4$, $\mathrm{PCHCH}_{3}$ ), 128.77, 129.73 (both m, CH), 130.74 (s, CH), 132.39, 132.57 (both dd, ${ }^{3} J_{\mathrm{CP}} \approx 4.7,{ }^{5} J_{\mathrm{CP}} \approx 2.4, \mathrm{CH}$ ), $140.09,141.30$ (both $\mathrm{d},{ }^{1} J_{\mathrm{CP}} \approx 43.4, \mathrm{C}$ ), $154.22,154.39$ (both dd, ${ }^{2} J_{\mathrm{CP}} \approx 28.4,{ }^{4} J_{\mathrm{CP}} \approx 5.9$, C). ${ }^{29} \mathrm{Si}\left\{{ }^{1} \mathrm{H}\right\}$ NMR $\left(\mathrm{CD}_{2} \mathrm{Cl}_{2}\right): \delta 31.15$ (brs). The crystals used in the $\mathrm{X}$-ray diffraction experiment were obtained from a THF solution stored at $253 \mathrm{~K}$.

Preparation of [ $\left.\mathrm{IrH}_{2}\left\{\kappa P, P, S i-S i(M e)\left(\mathrm{C}_{6} \mathrm{H}_{4}-2-\mathrm{PiPr}_{2}\right)_{2}\right\}(\mathrm{CO})\right]$ (9). A solution of $7(200 \mathrm{mg}, 0.30 \mathrm{mmol})$ in toluene/methanol $(10 / 1 \mathrm{~mL})$ was stirred under reflux for $1 \mathrm{~h}$. The resulting solution was filtered, evaporated to dryness, cooled to $213 \mathrm{~K}$ and treated with hexane $(3 \mathrm{~mL})$ to obtain a white solid. The solid was separated by decantation, washed with hexane, and dried in vacuo: yield $153 \mathrm{mg}$ (78\%). Anal. Cald. for $\mathrm{C}_{26} \mathrm{H}_{41} \mathrm{OP}_{2}$ SiIr: C, 47.91; $\mathrm{H}, 6.34$. Found: C, 47.90; H, 6.32. IR $\left(\mathrm{cm}^{-1}\right): 2090 v(\mathrm{IrH}), 1941 \mathrm{v}(\mathrm{CO}) .{ }^{1} \mathrm{H}$ $\operatorname{NMR}\left(\mathrm{CDCl}_{3}\right): \delta-13.95\left(\mathrm{td},{ }^{2} J_{\mathrm{HP}}=19.1,{ }^{2} J_{\mathrm{HH}}=3.4,1 \mathrm{H}, \mathrm{IrH}\right)$, $-10.97\left(\mathrm{td},{ }^{2} J_{\mathrm{HP}}=14.5,{ }^{2} J_{\mathrm{HH}}=3.4,1 \mathrm{H}, \mathrm{IrH}\right), 0.62\left(\mathrm{dvt},{ }^{3} J_{\mathrm{HH}}=\right.$ $\left.7.9,{ }^{3,5} N_{\mathrm{HP}}=15.2,6 \mathrm{H}, \mathrm{PCHCH}_{3}\right), 0.68\left(\mathrm{~s}, 3 \mathrm{H}, \mathrm{SiCH}_{3}\right), 1.07(\mathrm{~m}$, $\left.12 \mathrm{H}, \mathrm{PCHCH}_{3}\right), 1.27\left(\mathrm{dvt},{ }^{3} J_{\mathrm{HH}}=8.1{ }^{3,5} N_{\mathrm{HP}}=15.6,6 \mathrm{H}\right.$, $\mathrm{PCHCH}_{3}$ ), 2.35, 2.45 (both $\mathrm{m}, 2 \mathrm{H}$ each, $\mathrm{PCHCH}_{3}$ ), 7.25, 7.38 (both dd, ${ }^{3} J_{\mathrm{HH}}={ }^{3} J_{\mathrm{HH}} \approx 7.3,2 \mathrm{H}$ each, $\left.\mathrm{CH}\right), 7.48(\mathrm{~m}, 2 \mathrm{H}, \mathrm{CH})$, $8.13\left(\mathrm{~d},{ }^{3} J_{\mathrm{HH}}=7.3,2 \mathrm{H}, \mathrm{CH}\right) .{ }^{31} \mathrm{P}\left\{{ }^{1} \mathrm{H}\right\} \mathrm{NMR}\left(\mathrm{CDCl}_{3}\right): \delta 62.93(\mathrm{~s})$. ${ }^{13} \mathrm{C}\left\{{ }^{1} \mathrm{H}\right\}$ NMR $\left(\mathrm{CDCl}_{3}\right): \delta 5.83\left(\mathrm{~s}, \mathrm{SiCH}_{3}\right), 17.63\left(\mathrm{~s}, \mathrm{PCHCH}_{3}\right)$, $18.89\left(\mathrm{vt},{ }^{2,4} N_{\mathrm{CP}}=4.5, \mathrm{PCHCH}_{3}\right), 19.62\left(\mathrm{~s}, \mathrm{PCHCH}_{3}\right), 20.00$ (vt, $\left.{ }^{2,4} N_{\mathrm{CP}}=3.7, \mathrm{PCHCH}_{3}\right), 24.27\left(\mathrm{vt},{ }^{1,3} N_{\mathrm{CP}}=37.4, \mathrm{PCHCH}_{3}\right), 30.17$ (vt, ${ }^{1,3} N_{\mathrm{CP}}=27.5, \mathrm{PCHCH}_{3}$ ), $127.17\left(\mathrm{vt},{ }^{3,5} N_{\mathrm{CP}}=7.6, \mathrm{CH}\right), 129.03$ (vt, $\left.{ }^{2,4} N_{\mathrm{CP}}=6.4, \mathrm{CH}\right), 129.41(\mathrm{~s}, \mathrm{CH}), 132.76\left(\mathrm{vt},{ }^{3,4} N_{\mathrm{CP}}=18.5\right.$, CH), 144.96 (vt, $\left.{ }^{1,3} N_{\mathrm{CP}}=57.2, \mathrm{C}\right), 159.96\left(\mathrm{vt},{ }^{2,3} N_{\mathrm{CP}}=40.0, \mathrm{C}\right)$, $181.82\left(\mathrm{t},{ }^{2} J_{\mathrm{CP}}=5.7, \mathrm{CO}\right) .{ }^{29} \mathrm{Si}\left\{{ }^{1} \mathrm{H}\right\} \operatorname{NMR}\left(\mathrm{C}_{6} \mathrm{D}_{6}\right): \delta 34.87\left(\mathrm{t},{ }^{3} J_{\mathrm{SiP}}\right.$ $=5.9)$. The crystals used in the $\mathrm{X}$-ray diffraction experiment were obtained from a $\mathrm{CDCl}_{3}$ solution stored at $253 \mathrm{~K}$.

Preparation of [ $\left.\mathrm{IrH}_{4}\left\{\kappa P, P, S i-S i(M e)\left(\mathrm{C}_{6} \mathrm{H}_{4}-2-\mathrm{PiPr}_{2}\right)_{2}\right\}\right]$ (10). A suspension of 7 (255 mg, $0.40 \mathrm{mmol}$ ) in $15 \mathrm{~mL}$ of isopropanol was stirred under reflux for $4 \mathrm{~h}$. The resulting dark orange solution was evaporated to dryness and the residue was dissolved in toluene and filtered through Celite. The solution was then concentrated to ca. $0.5 \mathrm{~mL}$. and treated with hexane $(3 \mathrm{~mL})$ to get a white solid. The solid was separated by decantation, washed with hexane, and dried in vacuo: yield $185 \mathrm{mg}$ (74\%). The spectroscopic data obtained for the solid dissolved in $\mathrm{C}_{6} \mathrm{D}_{6}$ match those previously published for complex $\mathbf{1 0}$ in reference 17. 


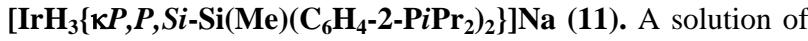
$1(33.0 \mathrm{mg}, 0.05 \mathrm{mmol})$ in THF- $d_{8}(0.5 \mathrm{~mL})$ was treated with $\mathrm{NaH}$ ( $8.0 \mathrm{mg}, 0.32 \mathrm{mmol}$ ) and stored at $280 \mathrm{~K}$. Periodic NMR monitoring of the reaction indicated the complete disappearing of the starting material after 5 days at this temperature. The low temperature NMR spectra indicated the selective formation of two new compounds in an approximate molar ratio 9:1, that correspond to isomers 11-fac and 11-mer, respectively. Data for 11-fac: ${ }^{1} \mathrm{H}$ NMR $\left(250 \mathrm{~K}, \mathrm{THF}-d_{8}\right): \delta-14.92\left(\mathrm{~m},{ }^{2} J_{\mathrm{HP}}=108.0,20.0,{ }^{2} J_{\mathrm{HH}}=\right.$ $6.5,2 \mathrm{H}, \mathrm{IrH}),-12.38\left(\mathrm{tt},{ }^{2} J_{\mathrm{HP}}=12.8,{ }^{2} J_{\mathrm{HH}}=6.5,1 \mathrm{H}, \mathrm{IrH}\right), 0.55$ $\left(\mathrm{dd},{ }^{3} J_{\mathrm{HP}}=12.2,{ }^{3} J_{\mathrm{HH}}=6.8,6 \mathrm{H}, \mathrm{PCHCH}{ }_{3}\right), 0.61\left(\mathrm{~s}, 3 \mathrm{H}, \mathrm{SiCH}_{3}\right)$, $0.65\left(\mathrm{dd},{ }^{3} J_{\mathrm{HP}}=13.4,{ }^{3} J_{\mathrm{HH}}=6.7,6 \mathrm{H}, \mathrm{PCHCH}_{3}\right), 1.10\left(\mathrm{dd},{ }^{3} J_{\mathrm{HP}}=\right.$ $13.0,{ }^{3} J_{\mathrm{HH}}=6.5,12 \mathrm{H}, \mathrm{PCHCH}$ ), 1.89, 2.03 (both m, $2 \mathrm{H}$ each, $\mathrm{PCHCH}_{3}$ ), 6.97, 7.07 ((both dd, ${ }^{3} J_{\mathrm{HH}}={ }^{3} J_{\mathrm{HH}} \approx 7.3,2 \mathrm{H}$ each, $\mathrm{CH}$ ), $7.43\left(\mathrm{dd},{ }^{3} J_{\mathrm{HH}} \approx 7.3,{ }^{3} J_{\mathrm{HP}}=4.1,2 \mathrm{H}, \mathrm{CH}\right), 7.83\left(\mathrm{~d},{ }^{3} J_{\mathrm{HH}} \approx 7.3,2 \mathrm{H}\right.$, $\mathrm{CH}) .{ }^{31} \mathrm{P}\left\{{ }^{1} \mathrm{H}\right\}$ NMR $\left(250 \mathrm{~K}, \mathrm{THF}-d_{8}\right): \delta 57.41(\mathrm{~s}) .{ }^{13} \mathrm{C}\left\{{ }^{1} \mathrm{H}\right\}$ NMR $\left(250 \mathrm{~K}, \mathrm{THF}-d_{8}\right): \delta 5.16\left(\mathrm{t},{ }^{3} J_{\mathrm{CP}}=3.4, \mathrm{SiCH}_{3}\right), 19.88(\mathrm{~s}$, $\left.\mathrm{PCHCH}_{3}\right), 20.23\left(\mathrm{t}, J_{\mathrm{CP}}=2.5, \mathrm{PCHCH}_{3}\right), 21.58\left(\mathrm{t}, J_{\mathrm{CP}}=3.7\right.$, $\mathrm{PCHCH}_{3}$ ), 22.79 (s, $\mathrm{PCHCH}_{3}$ ), 27.20, 28.00 (both m, $\mathrm{PCHCH}_{3}$ ), $125.88\left(\mathrm{t},{ }^{3,5} J_{\mathrm{CP}}=2.2, \mathrm{CH}\right), 127.96(\mathrm{~s}, \mathrm{CH}), 128.26\left(\mathrm{t},{ }^{2,4} J_{\mathrm{CP}}=\right.$ 1.2, CH), 132.47 (m, CH), 151.59 (m, C), 164.48 (m, C). ${ }^{29} \mathrm{Si}\left\{{ }^{1} \mathrm{H}\right\}$ NMR $\left(250 \mathrm{~K}, \mathrm{THF}-d_{8}\right): \delta 35.51\left(\mathrm{t},{ }^{3} J_{\mathrm{SiP}}=8.1\right)$. Data for 11-mer: ${ }^{1}$ H NMR (250 K, THF- $\left.d_{8}\right): \delta-16.25\left(\mathrm{tdd},{ }^{2} J_{\mathrm{HP}} \approx 19.4,{ }^{2} J_{\mathrm{HH}}={ }^{2} J_{\mathrm{HH}}\right.$, $=4.2,1 \mathrm{H}, \mathrm{IrH}),-14.92\left(\mathrm{tdd},{ }^{2} J_{\mathrm{HP}} \approx 11.3,{ }^{2} J_{\mathrm{HH}}={ }^{2} J_{\mathrm{HH}}=4.2,1 \mathrm{H}\right.$, $\mathrm{IrH}),-13.34\left(\mathrm{tdd},{ }^{2} J_{\mathrm{HP}} \approx 14.6,{ }^{2} J_{\mathrm{HH}}={ }^{2} J_{\mathrm{HH}}=4.2,1 \mathrm{H}, \mathrm{IrH}\right), 0.50$ (s, $\left.3 \mathrm{H}, \mathrm{SiCH}_{3}\right), 0.62\left(\mathrm{~m}, 6 \mathrm{H}, \mathrm{PCHCH}_{3}\right), 1.04\left(\mathrm{~m}, 12 \mathrm{H}, \mathrm{PCHCH}_{3}\right)$, $1.16\left(\mathrm{dvt},{ }^{3} J_{\mathrm{HH}}=6.8,{ }^{3,5} N_{\mathrm{HP}}=14.3,6 \mathrm{H}, \mathrm{PCHCH}_{3}\right), 1.80,2.31$ (both $\mathrm{m}, 2 \mathrm{H}$ each, $\mathrm{PCHCH}$ ), 7.01, 7.12 (both dd, ${ }^{3} J_{\mathrm{HH}}={ }^{3} J_{\mathrm{HH}}, \approx$ 7.2, $2 \mathrm{H}$ each, $\mathrm{CH}), 7.40(\mathrm{~m}, 2 \mathrm{H}, \mathrm{CH}), 8.05\left(\mathrm{~d},{ }^{3} \mathrm{~J}_{\mathrm{HH}} \approx 7.2,2 \mathrm{H}\right.$, $\mathrm{CH}) .{ }^{31} \mathrm{P}\left\{{ }^{1} \mathrm{H}\right\}$ NMR $\left(250 \mathrm{~K}, \mathrm{THF}-d_{8}\right): \delta 68.17$ (s). ${ }^{13} \mathrm{C}\left\{{ }^{1} \mathrm{H}\right\}$ NMR $\left(250 \mathrm{~K}, \mathrm{THF}-d_{8}\right): \delta 8.98\left(\mathrm{t},{ }^{3} J_{\mathrm{CP}}=0.9, \mathrm{SiCH}_{3}\right), 17.62(\mathrm{~s}$, $\mathrm{PCHCH}_{3}$ ), 19.77 (vt, $\left.{ }^{2,4} N_{\mathrm{CP}}=9.0, \mathrm{PCHCH}_{3}\right), 20.97$ (vt, ${ }^{2,4} N_{\mathrm{CP}}=$ 3.3, $\mathrm{PCHCH}_{3}$ ), 21.93 (vt, ${ }^{2,4} N_{\mathrm{CP}}=5.1, \mathrm{PCHCH}_{3}$ ), 23.11 (vt, ${ }^{1,3} N_{\mathrm{CP}}$ $=33.5, \mathrm{PCHCH}_{3}$ ), 32.49 (vt, $\left.{ }^{1,3} N_{\mathrm{CP}}=24.0, \mathrm{PCHCH}_{3}\right), 125.56(\mathrm{vt}$, $\left.{ }^{3,5} N_{\mathrm{CP}}=5.4, \mathrm{CH}\right), 127.88(\mathrm{~s}, \mathrm{CH}), 128.94\left(\mathrm{vt},{ }^{2,4} N_{\mathrm{CP}}=3.5, \mathrm{CH}\right)$, $132.43(\mathrm{~m}, \mathrm{CH}), 149.90\left(\mathrm{vt},{ }^{1,3} N_{\mathrm{CP}}=53.2, \mathrm{C}\right), 165.34\left(\mathrm{vt},{ }^{2,4} N_{\mathrm{CP}}=\right.$ 45.7, C). ${ }^{29} \mathrm{Si}\left\{{ }^{1} \mathrm{H}\right\} \operatorname{NMR}\left(250 \mathrm{~K}, \mathrm{THF}-d_{8}\right): \delta 40.36\left(\mathrm{t},{ }^{3} J_{\mathrm{SiP}}=\right.$ 11.2). The crystals used in the $\mathrm{X}$-ray diffraction experiment were obtained from a THF solution stored at $253 \mathrm{~K}$.

Computational details. The PBE1PBE (also known as $\mathrm{PBE} 0)^{34}$ and $\mathrm{mPW} 1 \mathrm{k}^{35}$ calculations were carried out in Gaussian 09 (rev A2) using tight optimizations and the ultrafine integration grid (a pruned $(99,590)$ grid). The basis sets included 6$31+G(3 p d)$ for the hydrides, Def2QZVPP (with the corresponding ECP) for Ir, 6-311+G(d) for P and Si atoms, and 6-31+G(d,p) for all other atoms. The default PCM method (solvent = tetrahydrofuran) was used in all Gaussian 09 calculations with the UFF radii scaled by 1.1 (explicit hydrogens). The MN15- $\mathrm{L}^{36}$ calculations of this work were carried out in Gaussian $16^{37}$ using Def2QZVP (with def2 ECP) for Ir and Def2TZVP basis set for all other atoms together with the W06 density fitting basis set. ${ }^{38,39}$ The polarizable continuum model (IEFPCM) was used in the Gaussian 16 calculations in THF solvent, with the radii and non-electrostatic terms of Truhlar and co-workers' SMD solvation model (scrf=smd). ${ }^{40}$ All optimized geometries were verified to have the correct number of negative harmonic frequencies by frequency calculations which also provided the reported enthalpies and free energies at $298.15 \mathrm{~K}$.

Structural analysis of complexes $1,2+3,7,8,9$, and 11 . Xray data were collected at $100.0(2) \mathrm{K}$ on Bruker Smart APEX CCD (1, 7, 8 and 11) and Smart APEX CCD DUO (2+3 and 9) diffractometers using graphite-monochromated Mo K $\alpha$ radiation $(\lambda=0.71073 \AA)$. Single crystals were mounted on a fiber and covered with protective perfluoropolyether. Data were collected over the complete sphere by a combination of four sets $(\mathbf{1}, \mathbf{2 + 3}, \mathbf{7}$ and $\mathbf{9}$ ) or three sets (8 and 11). Each frame exposure time was 20
(1, 7 and 11), $30(3+2), 10(9)$ or 5 s (8), covering $0.3^{\circ}$ in $\omega$. Data were corrected for absorption by using a multi-scan method applied with the SADABS program. ${ }^{41}$ The structures were solved by the Patterson method and refined by full-matrix least squares on $F^{2}$ using the Bruker SHELXTL program package, ${ }^{42}$ including isotropic and subsequently anisotropic displacement parameters for all non-hydrogen non-disordered atoms. Weighted $R$ factors $\left(\mathrm{R}_{w}\right)$ and goodness of fit $(S)$ are based on $F^{2}$, and conventional $R$ factors are based on $F$.

Data for 1. $\mathrm{C}_{25} \mathrm{H}_{40} \mathrm{ClP}_{2} \mathrm{SiIr}$, mol wt 658.27; yellow irregular block, $0.20 \times 0.04 \times 0.04 \mathrm{~mm}^{3}$; monoclinic, space group $C 2 / c ; a=$ 32.1770(18) $\AA, b=11.5057(7) \AA, c=15.3676(9) \AA ; \beta=$ 99.8800(10); $Z=8 ; V=5605.0(6) \AA^{3} ; D_{\text {calc }}=1.560 \mathrm{~g} \mathrm{~cm}^{-3} ; \mu=$ $5.027 \mathrm{~mm}^{-1}$, minimum and maximum transmission factors 0.500 and $0.710 ; 2 \theta_{\max }=57.60 ; 32669$ reflections collected, 6864 unique $[R($ int $)=0.0334]$; number of data/restrains/parameters 6864/0/284; final GoF 0.973, $R 1=0.0233$ [5845 reflections $I>$ $2 \sigma(I)], w R 2=0.0582$ for all data; largest peak and hole 2.826 (close to the Ir atoms) and -0.611 e $\AA^{-3}$. Hydrogen atoms (except the hydride) were calculated using a restricted riding model on their respective carbon atoms with the thermal parameter related to the bonded atom. The hydride was refined freely.

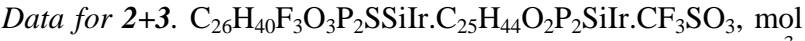
wt 1579.81; yellow irregular block, $0.10 \times 0.08 \times 0.06 \mathrm{~mm}^{3}$; triclinic, space group $P_{-} 1$; $a=12.3098(9) \AA, b=15.0326(11) \AA, c$ $=18.0143(13) \AA ; \alpha=70.0400(10), \beta=86.9170(10), \gamma=$ 85.6840(10); $Z=2 ; V=3123.0(4) \AA^{3} ; D_{\text {calc }}=1.680 \mathrm{~g} \mathrm{~cm}^{-3} ; \mu=$ $4.530 \mathrm{~mm}^{-1}$, minimum and maximum transmission factors 0.831 and $1.000 ; 2 \theta_{\max }=59.14 ; 33075$ reflections collected, 15865 unique $[R($ int $)=0.0347]$; number of data/restrains/parameters 15865/2/727; final GoF 0.871, $R 1=0.0290$ [11870 reflections $I>$ $2 \sigma(I)], w R 2=0.0538$ for all data; largest peak and hole 1.852 (close to the Ir atoms) and -1.027 e $\AA^{-3}$. Hydrogen atoms of both water ligands were observed in the difference Fourier maps and refined freely. Hydride ligands were observed in the difference Fourier maps and refined fixing the $\mathrm{Ir}-\mathrm{H}$ bond lengths to 1.59(1), average value found in The Cambridge Structural Database. The rest of the hydrogen atoms were calculated and refined using a restricted riding model on their respective carbon atoms.

Data for 7. $\mathrm{C}_{25} \mathrm{H}_{44} \mathrm{BP}_{2} \mathrm{SiIr}$, mol wt 637.66; colorless irregular block, $0.32 \times 0.18 \times 0.18 \mathrm{~mm}^{3}$; triclinic, space group $P_{-} 1 ; a=$ 11.7034(7) $\AA, b=14.9572(9) \AA, c=16.5817(10) \AA ; \alpha=$ 104.1290(10), $\beta=95.3820(10), \gamma=92.0490(10) ; Z=4 ; V=$ 2797.2(3) $\AA^{3} ; D_{\text {calc }}=1.514 \mathrm{~g} \mathrm{~cm}^{-3} ; \mu=4.941 \mathrm{~mm}^{-1}$, minimum and maximum transmission factors 0.254 and 0.455 ; $2 \theta_{\max }=$ $57.60 ; 34963$ reflections collected, 13216 unique $[R($ int $)=$ 0.0294]; number of data/restrains/parameters 13216/0/599; final GoF 0.965, $R 1=0.0218$ [11911 reflections $I>2 \sigma(I)], w R 2=$ 0.0564 for all data; largest peak and hole 2.087 (close to the Ir atoms) and $-0.970 \mathrm{e} \AA^{-3}$. Hydrogen atoms (except hydrides) were calculated using a restricted riding model on their respective carbon atoms with the thermal parameter related to the bonded atom. Hydrides were refined freely.

Data for 8. $\mathrm{C}_{50} \mathrm{H}_{84} \mathrm{BP}_{4} \mathrm{Si}_{2} \mathrm{Ir}_{2} \mathrm{BF}_{4} \cdot 2.7\left(\mathrm{C}_{4} \mathrm{H}_{8} \mathrm{O}\right)$, mol wt 1528.26; colorless irregular block, $0.22 \times 0.14 \times 0.08 \mathrm{~mm}^{3}$; triclinic, space group $P_{-} 1 ; a=15.0151(15) \AA, b=16.3668(17) \AA, \quad c=$ 16.8562(17) $\AA ; \alpha=95.1790(10), \quad \beta=110.5820(10), \gamma=$ 102.7900(10); $Z=2 ; V=3717.1(7) \AA^{3} ; D_{\text {calc }}=1.358 \mathrm{~g} \mathrm{~cm}^{-3} ; \mu=$ $3.740 \mathrm{~mm}^{-1}$, minimum and maximum transmission factors 0.502 and $0.672 ; 2 \theta_{\max }=56.38 ; 34340$ reflections collected, 16892 unique $[R(\mathrm{int})=0.0571]$; number of data/restrains/parameters 16892/171/781; final GoF 0.934, $R 1=0.0564$ [9765 reflections $I$ $>2 \sigma(I)], w R 2=0.1498$ for all data; largest peak and hole 3.168 and -2.007 e $\AA^{-3}$. Hydride ligands were observed in the differ- 
ence Fourier maps and refined with fixed thermal parameters and positional restrains. The rest of the hydrogen atoms were calculated and refined using a restricted riding model on their respective carbon atoms. Four crystallization molecules of tetrahydrofuran were observed in the unit cell and refined with restrains in the geometry and thermal parameters. The highest electronic residuals were observed in the proximity of these tetrahydrofuran molecules.

Data for 9. $\mathrm{C}_{26} \mathrm{H}_{42} \mathrm{OP}_{2} \mathrm{SiIr}$, mol wt 651.84; colorless irregular block, $0.20 \times 0.06 \times 0.04 \mathrm{~mm}^{3}$; monoclinic, space group $P 21 / n$; $a$ $=8.9090(8) \AA, b=21.3533(19) \AA, c=14.9136(13) \AA ; \beta=$ 105.0290(10); $Z=4 ; V=2740.1(4) \AA^{3} ; D_{\text {calc }}=1.580 \mathrm{~g} \mathrm{~cm}^{-3} ; \mu=$ $5.049 \mathrm{~mm}^{-1}$, minimum and maximum transmission factors 0.494 and $0.678 ; 2 \theta_{\max }=59.10 ; 28307$ reflections collected, 7181 unique $[R($ int $)=0.0367]$; number of data/restrains/parameters 7181/0/297; final GoF 0.891, $R 1=0.0220$ [5966 reflections $I>$ $2 \sigma(I)], w R 2=0.0457$ for all data; largest peak and hole 1.594 (close to the Ir atoms) and $-0.946 \mathrm{e} \AA^{-3}$. Hydrogen atoms (except hydrides) were calculated using a restricted riding model on their respective carbon atoms with the thermal parameter related to the bonded atom. Hydrides were refined freely.

Data for 11. $\mathrm{C}_{25} \mathrm{H}_{42} \mathrm{P}_{2}$ SiIr.Na. $\mathrm{C}_{4} \mathrm{H}_{8} \mathrm{O}$, mol wt 719.93; colorless irregular block, $0.36 \times 0.18 \times 0.14 \mathrm{~mm}^{3}$; monoclinic, space group $P 21 / c ; a=31.0378(15) \AA, b=21.1623(10) \AA, c=20.2672(10) \AA$; $\beta=107.3840(10) ; Z=16 ; V=12704.1(11) \AA^{3} ; D_{\text {calc }}=1.506 \mathrm{~g}$ $\mathrm{cm}^{-3} ; \mu=4.376 \mathrm{~mm}^{-1}$, minimum and maximum transmission factors 0.373 and $0.495 ; 2 \theta_{\max }=57.48 ; 116321$ reflections collected, 30225 unique $[R$ (int) $=0.0410]$; number of data/restrains/parameters 30225/12/1334; final GoF 1.004, $R 1=$ 0.0360 [22761 reflections $I>2 \sigma(I)], w R 2=0.0750$ for all data; largest peak and hole 2.570 (close to the Ir atoms) and $-1.758 \mathrm{e}$ $\AA^{-3}$. Hydride ligands were observed in the difference Fourier maps but not refined properly. Because of that, all $\mathrm{Ir}-\mathrm{H}$ bond lengths were fixed to the same value, 1.59(1) $\AA$, average value found in The Cambridge Structural Database, and restraints were applied to the hydride's thermal parameters. The rest of the hydrogen atoms were calculated and refined using a restricted riding model on their respective carbon atoms. A crystallization molecule of tetrahydrofuran was observed in the unit cell and refined freely.

\section{ASSOCIATED CONTENT}

\section{Supporting Information}

The Supporting Information is available free of charge on the ACS Publications website at DOI:

NMR spectra of complexes 2-11, details of the NMR kinetic and thermodynamic determinations, and energies of the calculated compounds and transitions states (PDF)

Crystallographic data for 1, 2+3, 7, 8, 9, and 11 (CIF)

Calculated complex coordinates (XYZ)

\section{AUTHOR INFORMATION}

\section{Corresponding Author}

* E-mail for E.S.: sola@unizar.es

*E-mail for M.M.; martam@unizar.es

ORCID

Eduardo Sola: 0000-0001-5462-6189

Marta Martín: 0000-0001-7819-670X

Dmitry G. Gusev: 0000-0003-3302-356X

\section{Notes}

The authors declare no competing financial interests.

\section{ACKNOWLEDGMENT}

Financial support from the Spanish MINECO (Grants CTQ201231774, BES2013-063359 (to E. Suárez) and CTQ2015-64486-R), Gobierno de Aragón (E75), FEDER, and the European Social Fund is acknowledged.

\section{REFERENCES}

(1) Norton, J. R.; Sowa, J. Introduction: Metal Hydrides. Chem. Rev. 2016, 116, 8315-8317, and all reviews in this special issue.

(2) Iridium Catalysis. Top. Organomet. Chem. 2011, 34

(3) Iridium Complexes in Organic Synthesis: Oro, L. A., Claver, C., Eds.; Wiley-VCH: Weinheim 2009.

(4) Blaser, H. -U. In ref. 3; Chapter 1, pp 1-14.

(5) Verendel, J. J.; Pámies, O.; Diéguez, M.; Andersson, P. G. Asymmetric Hydrogenation of Olefins Using Chiral Crabtreetype Catalysts: Scope and Limitations. Chem. Rev. 2014, 114, 2130-2169.

(6) Hartwig, J. F. Evolution of $\mathrm{C}-\mathrm{H}$ Bond Functionalization from Methane to Methodology. J. Am. Chem. Soc. 2016, 138, 2-24.

(7) Esteruelas, M. A.; López, A. M.; Oliván, M. Polyhydrides of Platinum Group Metals: Nonclassical Interactions and $\sigma$-Bond Activation Reactions. Chem. Rev. 2016, 116, 8770-8847.

(8) Kumar, A.; Zhou, T.; Emge, T. J.; Mironov, O.; Saxton, R. J.; Krogh-Jespersen, K.; Golman, A. S. Dehydrogenation of nAlkanes by Solid-Phase Molecular Pincer-Iridium Catalysts. High Yields of $\alpha$-Olefin Product. J. Am. Chem. Soc. 2015, 137, 9894-9911.

(9) Hartwig, J. F. Borylation and Silylation of C-H Bonds: A Platform for Diverse $\mathrm{C}-\mathrm{H}$ Bond Functionalizations. Acc. Chem. Res. 2012, 45, 864-873.

(10) Belkova, N. V.; Epstein, L. M.; Filippov, O. A.; Shubina, E. S. Hydrogen and Dihydrogen Bonds in the Reactions of Metal Hydrides. Chem. Rev. 2016, 116, 8545-8587.

(11) Gusev, D. G.; Berke, H. Hydride Fluxionality in Transiton Metal Complexes: An Approach to the Understanding of Mechanistic Features and Structural Diversities. Chem. Ber. 1996, 129, 11431155.

(12) Eisenstein, O.; Crabtree, R. H. Outer Sphere Hydrogenation Catalysis. New. J. Chem. 2013, 37, 21-27.

(13) Coe, B. J.; Glenwright, S. J. Trans-effects in Octahedral Transition Metal Complexes. Coord. Chem. Rev. 2000, 203, 5-80.

(14) Turculet, L. In Pincer and Pincer-Type Complexes. Applications in Organic Synthesis and Catalysis; Szabo, K. J., Wendt, O. F. Eds.; Wiley-VCH: Weinheim 2014; Chapter 6, pp 149-188.

(15) For leading references, see: Shih, W. -C.; Gu, W.; MacInnis, M. C.; Timpa, S. D.; Bhuvanesh, N.; Zhou, J.; Ozerov, O. V. Facile Insertion of Rh and Ir into a Boron-Phenyl Bond, Leading to Boryl/Bis(phosphine) PBP Pincer Complexes. J. Am. Chem. Soc. 2016, 138, 2086-2089.

(16) Sola, E.; García-Camprubí, A.; Andrés, J. L.; Martín, M.; Plou, P. Iridium Compounds with $\kappa-P, P, S i$ (biPSi) Pincer Ligands: Favoring Reactive Structures in Unsaturated Complexes. J. Am. Chem. Soc. 2010, 132, 9111-9121.

(17) Suh, H.-W.; Schmeier, T. J.; Hazari, N.; Kemp, R. A.; Takase, M. K. Experimental and Computational Studies of the Reaction of Carbon Dioxide with Pincer-Supported Nickel and Palladium Hydrides. Organometallics 2012, 31, 8225-8236.

(18) For a precedent of dihydrogen complex in a closely related ligand environment, see: Connor, B. A.; Rittle, J.; VanderVelde, D.; Peters, J. C. A Ni ${ }^{0}\left(\eta^{2}-(\mathrm{Si}-\mathrm{H})\right)\left(\eta^{2}-\mathrm{H}_{2}\right)$ Complex That Mediates Facile $\mathrm{H}$ Atom Exchange between Two $\sigma$-Ligands. Organometallics 2016, 35, 686-690.

(19) Fang, H.; Choe, Y.-K.; Li, Y.; Shimada, S. Synthesis, Structure, and Reactivity of Hydridoiridium Complexes Bearing a PincerType PSiP Ligand. Chem. Asian. J. 2011, 6, 2512-2521.

(20) Li, Y. -H.; Zhang, Y.; Ding, X. -H. Synthesis, Structure, and Catalytic Behavior of a PSiP Pincer-Type Iridium(III) Complex. Inorg. Chem. Comun. 2011, 14, 1306-1310. 
(21) MacLean, D. F.; McDonald, R.; Ferguson, M. J.; Caddell, A. J.; Turculet, L. Room Temperature Benzene $\mathrm{C}-\mathrm{H}$ Activation by a New [PSiP]Ir Pincer Complex. Chem. Commun. 2008 5146-5148.

(22) García-Camprubí, A.; Martín, M.; Sola, E. Addition of Water Across $\mathrm{Si}-\mathrm{Ir}$ Bonds in Iridium Complexes with $\kappa-P, P, S i$ (biPSi) Pincer Ligands. Inorg. Chem. 2010, 49, 10649-10657.

(23) For a previous NMR-based discussion on the coordination mode of this PSiP ligand, see: (a) Bernal, M. J.; Torres, O.; Martín, M.; Sola, E. Reversible Insertion of Carbenes into Ruthenium-Silicon Bonds. J. Am. Chem. Soc. 2013, 135, 19008-19015. See also: (b) Bernal, M. J.; Martín, M.; Sola, E. Arene and Hydride Complexes of Ruthenium with fac PSiP Pincer Ligands. Z. Anorg. Allg. Chem. 2015, 641, 2122-2128.

(24) Crabtree, R. H. Dihydrogen Complexation. Chem. Rev. 2016, $116,8750-8769$.

(25) The H/D scrambling in the presence of $D_{2}$ also works for the hydride ligand of the starting complex 1, although much slowly (hours). Hydride deuteration provokes a characteristic isotopic shift of +0.05 ppm in the ${ }^{31} \mathrm{P}\left\{{ }^{1} \mathrm{H}\right\}$ NMR signal of $\mathbf{1}$.

(26) Morris, R. H. Dihydrogen, Dihydride and in Between: NMR and Structural Properties of Iron Group Complexes. Coord. Chem. Rev. 2008, 252, 2381-2394.

(27) Besora, M.; Lledós, A. Coordination Modes and Hydride Exchange Dynamics in Transition Metal Tetrahydroborate Complexes. Struct. Bond. 2008, 130, 149-202.

(28) For recent work with leading references, see: (a) Melnick, J. G.; Radosevich, A. T.; Villagrán, D.; Nocera, D. G. Decarbonylation of Ethanol to Methane, Carbon Monoxide and Hydrogen by a [PNP]Ir Complex. Chem. Commun. 2010, 46, 79-81 and (b) Olsen, E. P. K.; Singh, T.; Harris, P.; Andersson, P. G.; Madsen, R. Experimental and Theoretical Mechanistic Investigation of the Iridium-Catalyzed Dehydrogenative Decarbonylation of Primary Alcohols. J. Am. Chem. Soc. 2015, 137, 834-842.

(29) Suh, H. -W.; Balcells, D.; Edwards, A. J.; Guard, L. M.; Hazari, N.; Marder, E. A.; Mercado, B. Q.; Repisky, M. Understanding the Solution and Solid-State Structures of Pd and Pt PSiP PincerSupported Hydrides. Inorg. Chem. 2015, 54, 11411-11422.

(30) Wu, S.; Li, X.; Xiong, Z.; Xu, W.; Lu, Y.; Sun, H. Synthesis and Reactivity of Silyl Iron, Cobalt, and Nickel Complexes Bearing a [PSiP]-Pincer Ligand via Si-H Bond Activation. Organometallics 2013, 32, 3227-3237.

(31) Joost, M.; Mallet-Ladeira, S.; Miqueu, K.; Amgoune, A.; Bourissou, D. $\sigma$-SiH Complexes of Copper: Experimental Evidence and Computational Analysis. Organometallics 2013, 32, 898-902.

(32) Takaya, J.; Iwasawa, N. Reaction of $\operatorname{Bis}\left(o_{-}\right.$ phosphinophenyl)silane with $\mathrm{M}\left(\mathrm{PPh}_{3}\right)_{4}(\mathrm{M}=\mathrm{Ni}, \mathrm{Pd}, \mathrm{Pt})$ : Synthesis and Structural Analysis of $\eta^{2}-(\mathrm{Si}-\mathrm{H}) \operatorname{Metal}(0)$ and Pentacoordinate Silyl Metal(II) Hydride Complexes of the Ni Triad Bearing a PSiP-Pincer Ligand. Dalton Trans. 2011, 40, 8814-8821.

(33) Hebden, T. J.; Goldberg, K. I.; Heinekey, D. M.; Zhang, X.; Emge, T. J.; Goldman, A. S.; Krogh-Jespersen, K. Dihydrogen/Dihydride or Tetrahydride? An Experimental and Computational Investigation of Pincer Iridium Polyhydrides. Inorg. Chem. 2010, 49, 1733-1742.

(34) Adamo, C.; Barone, V. Toward Reliable Density Functional Methods without Adjustable Parameters: The PBE0 Model. J. Chem. Phys. 1999, 110, 6158-6170.

(35) (a) Lynch, B. J.; Fast, P. L.; Harris, M.; Truhlar, D. G. Adiabatic Connection to Kinetics. J. Phys. Chem. A 2000, 104, 4811-4815. (b) Zhao, Y.; Pu, J.; Lynch, B. J.; Truhlar, D. G. Tests of SecondGeneration and Third-Generation Density Functionals for Thermochemical Kinetics. Phys. Chem. Chem. Phys. 2004, 6, 673-676.

(36) Yu, H. S.; He, H; Truhlar, D. G. MN15-L: A New Local Exchange-Correlation Functional for Kohn-Sham Density Functional Theory with Broad Accuracy for Atoms, Molecules, and Solids. J. Chem. Theory Comput. 2016, 12, 1280-1293.

(37) Frisch, M. J.; Trucks, G. W.; Schlegel, H. B.; Scuseria, G. E.; Robb, M. A.; Cheeseman, J. R.; Scalmani, G.; Barone, V.; Petersson, G. A.; Nakatsuji, H.; Li, X.; Caricato, M.; Marenich, A. V.; Bloino, J.; Janesko, B. G.; Gomperts, R.; Mennucci, B.; Hratchian, H. P.; Ortiz, J. V.; Izmaylov, A. F.; Sonnenberg, J. L.; Williams-Young, D.; Ding, F.; Lipparini, F.; Egidi, F.; Goings, J.; Peng, B.; Petrone, A.; Henderson, T.; Ranasinghe, D.;
Zakrzewski, V. G.; Gao, J.; Rega, N.; Zheng, G.; Liang, W.; Hada, M.; Ehara, M.; Toyota, K.; Fukuda, R.; Hasegawa, J.; Ishida, M.; Nakajima, T.; Honda, Y.; Kitao, O.; Nakai, H.; Vreven, T.; Throssell, K.; Montgomery, J. A., Jr.; Peralta, J. E.; Ogliaro, F.; Bearpark, M. J.; Heyd, J. J.; Brothers, E. N.; Kudin, K. N.; Staroverov, V. N.; Keith, T. A.; Kobayashi, R.; Normand, J.; Raghavachari, K.; Rendell, A. P.; Burant, J. C.; Iyengar, S. S.; Tomasi, J.; Cossi, M.; Millam, J. M.; Klene, M.; Adamo, C.; Cammi, R.; Ochterski, J. W.; Martin, R. L.; Morokuma, K.; Farkas, O.; Foresman, J. B.; Fox, D. J. Gaussian 16, Revision A.03; Gaussian, Inc., Wallingford CT, 2016.

(38) Weigend, F.; Ahlrichs, R. Balanced Basis Sets of Split Valence, Triple Zeta Valence and Quadruple Zeta Valence Quality for $\mathrm{H}$ to Rn: Design and Assessment of Accuracy. Phys. Chem. Chem. Phys. 2005, 7, 3297-3305.

(39) Weigend, F. Accurate Coulomb-Fitting Basis Sets for $\mathrm{H}$ to $\mathrm{Rn}$. Phys. Chem. Chem. Phys. 2006, 8, 1057-1065.

(40) Marenich, A. V.; Cramer, C. J.; Truhlar, D. G. Universal Solvation Model Based on Solute Electron Density and on a Continuum Model of the Solvent Defined by the Bulk Dielectric Constant and Atomic Surface Tensions. J. Phys. Chem. B 2009, 113, 6378-6396.

(41) (a) Blessing, R. H. An Empirical Correction for Absorption Anisotropy. Acta Crystallogr., Sect. A: Found. Crystallogr. 1995, 51, 33-38. (b) SADABS: Area-Detector Absorption Correction; Bruker-AXS, Madison, WI, 1996.

(42) (a) SHELXTL Package v. 6.14; Bruker-AXS, M., WI, 2000. (b) Sheldrick, G. M. A Short History of SHELX. Acta Crystallogr., Sect. A: Found. Crystallogr., 2008, 64, 112-122. 
Starting from the five-coordinate pincer precursor [ $\operatorname{IrClH}(\mathrm{PSiP})]$, this work describes synthetic routes towards hydride and polyhydride derivatives showing a variety of structural and electronic characteristics, as well as enhanced coordination and reaction capabilities. Their structure and dynamic behavior in solution indicate that, besides the trans influence of the silyl group, the spatial contour of the PSiP framework plays an essential role in this chemistry, conditioning phenomena as elusive as hydride ligand motions.

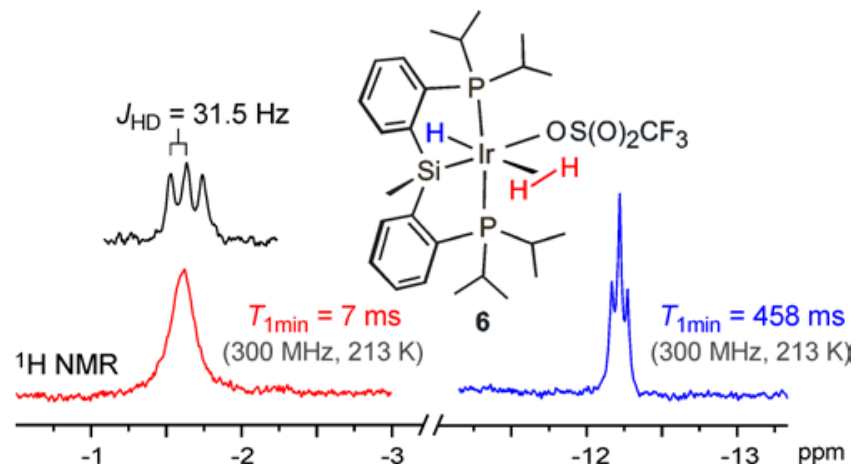

